\title{
TWO DECADES OF STATE LABOR LEGISLATION 1937-1957
}

\author{
HAROLD A. KaTŻ
}

$\mathrm{I}$ T Is now exactly twenty years since Wisconsin became the first state to adopt a labor relations act. During the first decade the national labor policy was embodied in the Wagner Act. ${ }^{1}$ The Taft-Hartley Act ${ }^{2}$ furnished the milieu in which the states legislated in the second decade. Of perhaps even greater significance to the states than the federal acts themselves, however, were the decisions of the United States Supreme Court in labor cases during the period. This was because, as the Court wrote:

The National Labor Management Relations Act ... leaves much to the states, though Congress has refrained from telling us how much. We must spell out from conflicting indications of Congressional will the area in which state action is still permissible. ${ }^{3}$

It is our purpose here to explore the areas of state action in the labor field in the last two decades. We shall study the significant types of legislation affecting labor and employment relations and the functioning and activities of labor unions. While recognizing that areas of state authority "are not susceptible of delimitation by fixed metes and bounds,"4 the material will be correlated with the significant Supreme Court decisions, recognizing that "this penumbral area can be rendered progressively clear only by the course of litigation."

\section{The State Labor Relations Acts}

A comprehensive code regulating labor relations is found in the twelve states, ${ }^{6}$ one territory, ${ }^{7}$ and one commonwealt ${ }^{8}$ which have adopted labor rela-

$\dagger$ Member of the Illinois Bar.

I National Labor Relations Act, 1935, 49 Stat. 449 (1935). For a study of this decade, see Millis and Katz, A Decade of State Labor Legislation: 1937-1947, 15 U. of Chi. L. Rev. 282 (1948).

${ }^{2}$ Labor Mranagement Relations Act, 1947, 61 Stat. 136 (1947), 29 U.S.C.A. \$ 151 (1956).

${ }^{3}$ Garner v. Teamsters Union, 346 U.S. 485,488 (1953).

${ }^{4}$ Weber v. Anheuser-Busch, Inc., 348 U.S. 468,480 (1954).

${ }^{5}$ Ibid. For a full discussion of the pre-emption doctrine, see Isaacson, Labor Relations Law: Federal v. State Jurisdiction, 42 A.B.A.J. 415 (1956).

${ }^{6}$ Colo. Rev. Stat. (1954) $\$ \$ 80-5-1$ et seq.; Conn. Gen. Stat. (1949) c. 370 , $\$ 7388$ et seq.; Kan. Gen. Stat. (1949) $\$ \$ 4 t-801$ et seq.; Mass. Ann. L. (1950) c. $150 \mathrm{~A}$, $\$ 1$ et seq.; Mich. Stat. Ann. (1950) Title 17, c. 154, \$17.451(1); Minn. Stat. Ann. (1947) $\$ 179.01$ et seq.; N.Y. Labor Law (McKinney, 1948) $\$$ 700 et seq.; Ore. Rev. Stat. (1955) $\$ \$ 662.610$ et seq.; Pa. Stat. Ann. (Purdon, 1952) Title 43, $\$ 211.1$ et seq.; R.I.L. (1941) c. 1066; Utah Code Ann. (1953) $\$ 3+1-1$ et seq.; Wis. Stat. Ann. (West, 1957) $\$ 111.01$ et seq. The Kansas and Oregon Acts are being included within this section even though they lack an important characteristic found in other acts-administration by a board or commission.

${ }^{7}$ Hawaii L. (1945) c. $72 \mathrm{~A}, \$ \$ 150.01$ et seq.

${ }^{*}$ Puerto Rico L. Ann. (1954) Title 29, c. 3, $\$ \$ 61$ et seq. 
tions acts. Although the Taft-Hartley Act invited enactment of compatible state legislation, ${ }^{9}$ no state has enacted such a law since the adoption of the federal statute in 1947. This contrasts with the rapid enactment of four "little Wagner Acts" in five states within months after the Supreme Court held the Wagner Act constitutional. ${ }^{10}$ Thereafter, only Rhode Island adopted such a statute, ${ }^{\text {"I }}$ and today, of the original group, only New York retains its "little Wagner Act" in substantially the original form. In 1939, Wisconsin, the first state to adopt a "little Wagner Act," replaced that act by the Wisconsin Employment Peace Act. ${ }^{12}$ The Wisconsin Act has been the precursor of subsequent legislation, state and federal, in its emphasis limiting the area of labor disputes to the primary disputants, ${ }^{13}$ as well as in its recognition of a right to refrain as well as a right to engage in union activity, ${ }^{14}$ and in its addition of union unfair labor practices. ${ }^{15}$ Both this statute and the Michigan Act of that same year attempted to justify themselves at least in part by a stated policy of protecting the consumer and parties not directly involved in labor disputes. ${ }^{16}$ The spirit of these 1939 statutes has dominated subsequent labor legislation, leading the trend away from laws which primarily protected union activity and fostered collective bargaining, toward legislation designed primarily to limit the area of labor's rights.

Procedurally the state labor relations acts are of three basic types. The most popular has been the administrative type, patterned on the National Labor Relations Act, which places the administration of the statute in an agency that combines the functions of investigation, prosecution and adjudication. A check against arbitrary action is provided, however, since unless there is voluntary compliance, the agency must go into the appropriate court to seek enforcement of its order. Charges are filed by private parties for investigation by the agency, but only the agency itself can issue a complaint which commences the formal

${ }^{9}$ Labor Management Relations Act, 1947, $§ 10(\mathrm{a}), 61$ Stat. 146 (1947), 29 U.S.C.A. $\$ 160$ (a) (1956). Alabama in 1949 adopted an act similar to the Taft-Hartley Act but made applicable only to Wilcox County, a non-industrial area in the state. Ala. Gen. Act No. 241 (1949). Acceptance of the Act was made subject to a special election held in September, 1956, and upon its approval in this referendum, it went into effect immediately thereafter, administered by the circuit judge of the county. State Labor Legislation in 1949. 70 MIonthly Lab. Rev. 42, 44 (1950). Subsequently, the Attorney General of Alabama, in an opinion dated July 19,1950 , held the entire Act to be unconstitutional on the ground that the ministerial functions given the judge contravened the Constitution of Alabama.

${ }^{10}$ National Labor Relations Board v. Jones \& Laughlin Steel Corp., 301 U.S. 1 (1937). The four states were Massachusetts, New York, Pennsylvania and Utah. See note 6 supra.

"1 R.I.L. (1941) c. 1066.

12 Wis. Stat. Ann. (West, 1957) $\S \$ 111.01$ et seq.

${ }^{13}$ Wis. Stat. Ann. (West, 1957) §111.01.

" Ibid. This right was always implicit under the Wagner Act but its specific enunciation was indicative of a new emphasis.

${ }^{15}$ Id., at $\$ 111.06$.

16 Id., at $\S 111.01(4)$. 
procedure. "The most conspicuous attributes of these administrative boards," a former NLRB chairman has written, "are preliminary investigation [of charges filed] by state employees, the encouragement of settlements between the parties consistent with the policies of the acts, the winnowing out of weak or frivolous cases which might otherwise be pressed to hearing by over-zealous private litigants, the elimination of protracted hearings wherever possible, and the evolution of a unified governmental policy on labor relations."17 Seven jurisdictions utilize the administrative technique-Connecticut, ${ }^{18}$ Massachusetts, ${ }^{19}$ New Xork, ${ }^{20}$ Oregon, ${ }^{21}$ Puerto Rico, ${ }^{22}$ Rhode Island ${ }^{23}$ and Utah. ${ }^{24}$ The remedies for unfair labor practices can be expertly tailored to cure the violation, but only by remedial, not punitive, orders. Puerto Rico adds a sanction: a violator of the Act cannot bid on any contract supported even in part by government funds, nor can he receive any permit, franchise or license from the Government, or subdivision thereof, for a period of one year. ${ }^{25}$

A quasi-judicial technique is utilized in a second group of jurisdictionsColorado, ${ }^{26}$ Hawaii, ${ }^{27}$ Pennsylvania ${ }^{28}$ and Wisconsin. ${ }^{29}$ The board occupies the position of a court of first resort. No attempt is made to investigate the merits of a complaint filed prior to hearing or to effect voluntary settlements; a hearing follows the filing of a complaint by a party as a matter of course. ${ }^{30}$ The parties are private litigants seeking to enforce private rights, ${ }^{31}$ and a party is always free to withdraw his complaint, without regard to whether the policies of the act are thereby effectuated. An alternative procedure is provided in Colorado under which the Commission can itself initiate a complaint, but its right in this regard is no greater than that of a private party. ${ }^{32}$ Redress in these four jurisdictions is remedial, except that a violation of the statute is made a misdemeanor

17 Herzog, The Labor Relations Acts of the States, 224 Annals 19, 22 (1942).

is Conn. Gen. Stat. (1949) c. 370, $\$ \$ 7394-5$.

19 Mass. Ann. L. (1950) c. $150 \mathrm{~A}, \$ \S 5-7$.

2" N.Y. Labor Law (AcKinney, 1918) § 706.

${ }^{21}$ Ore. Rev. Stat. (1955) c. 662.710.

${ }^{22}$ Puerto Rico L. Ann. (1954) Title 29, c. 3, $\$ 68$.

${ }^{23}$ R.I.L. (1941) c. 1066, \$\$3, 7.

${ }^{24}$ Utah Code Ann. (1953) \$34-1-10.

${ }^{25}$ Puerto Rico L. Ann. (1951) Title 29, c. $3, \$ 72$.

${ }^{28}$ Colo. Rev. Stat. (1954) $\$ 80-5-8(14)$.

${ }^{27}$ Hawaii L. (1945) c. 72., $\$ 4150.09$.

${ }^{2 x} \mathrm{~Pa}$. Stat. Ann. (Purdon, 1952) Title 43, \$211.8(b).

${ }^{23}$ Wis. Stat. Ann. (West, 1957) \$111.07.

${ }^{30}$ The language of the Pennsylvania statute might be interpreted to give the Board discretion in the issuance of a complaint. Pa. Stat. Ann. (Purdon, 1952) Title 43, $\$ 211.8(\mathrm{~b})(\mathrm{f})$.

${ }^{31}$ The Pennsylvania statute does permit the Attorney General, if he "sees fit, to participate in the prosecution of the case." Id., at $\$ 211.8(\mathrm{f})$.

${ }^{32}$ Colo. Rev. Stat. (1953) $\S 80-5-8(2)$ (a). 
in Colorado. ${ }^{33}$ In Colorado, ${ }^{34}$ Hawaii ${ }^{35}$ and Wisconsin, ${ }^{36}$ the statutes expressly provide that a party is free to pursue equitable or legal relief in courts of competent jurisdiction; Pennsylvania, like the administrative states, purports to give the state board exclusive power to prevent any person from engaging in an unfair labor practice. ${ }^{37}$

The established judicial system is utilized in the third group of states having labor relations acts-Kansas, ${ }^{38}$ Michigan ${ }^{39}$ and Minnesota. ${ }^{40}$ All proceedings to prevent or remedy unfair labor practices take place exclusively in the courts, with no labor relations board authorized to prosecute or to hear and determine such matters. Consequently, these states can be said to utilize "the court technique." 41 The commission of an unfair labor practice is made a misdemeanor under the Michigan statute, ${ }^{+2}$ while the remedy provided in Minnesota $^{43}$ and Kansas ${ }^{44}$ is injunctive relief. While the first two groups of states give priority in the courts to cases arising under the state labor relations act, no special treatment is accorded such litigation in states utilizing the "court technique." The inflexibility of remedy and the expense and other difficulties involved in prosecuting "private rights" in the courts appear to have resulted in little enforcement of these statutes in Michigan, Minnesota and Kansas. ${ }^{45}$

The most important features of the National Labor Relations Act, as amended, are the provisions for employer and union unfair labor practices and for the holding of representation elections. All of the state labor relations acts provide for some employer unfair labor practices, but those provided in the state acts of Kansas, Michigan, Minnesota and Oregon are significantly weaker than those provided in the federal act. Among the additional unfair labor

${ }^{33} \mathrm{Id}$., at $\$ 80-5-20$.

34 Colorado expressly provides civil liability for damages from an unfair labor practice. Id., at $\S \S 80-5-8(1), 80-5-19(1)$.

${ }^{35}$ Hawaii L. (1945) c. 72A, $\$ 4150.09(1)$.

${ }^{36}$ Wis. Stat. Ann. (West, 1957) $\$ 111.07(1)$.

${ }^{37} \mathrm{~Pa}$. Stat. Ann. (Purdon, 1952) Title 43, $\S 211.8(\mathrm{a})$. An exception always is the power of a state court to enjoin acts of violence. Allen-Bradley Local v. Wisconsin Board, 315 U.S. 740,749 (1942).

${ }^{38}$ Kan. Gen. Stat. (1949) $\S \S 44-811,44-814$.

${ }^{39}$ Mich. Stat. Ann. (1950) $\S 17.454$ (23)(c).

${ }^{40}$ Minn. Stat. Ann. (1947) $\$ 179.14$.

${ }^{4} \mathrm{~T}$ This is the same enforcement procedure provided in all the states which have piecemeal labor legislation not included in a labor relations act.

${ }^{42}$ Mich. Stat. Ann. (1950) § 17.454 (16)-(18).

${ }^{43}$ Minn. Stat. Ann. (1947) $§ 179.14$.

${ }^{44}$ The action may be at the instance of the Attorney General, the County Attorney or on complaint of any aggrieved party. Kan. Gen. Stat. (1949) $\S 44.810$.

${ }^{45}$ See Killingsworth, The Labor Relations Acts of the States: A Study in Public Policy 132-33 (1948). 
practices added are breach of contract in five jurisdictions, ${ }^{46}$ bargaining with a minority union in four jurisdictions, ${ }^{47}$ and refusing to accept the final determination of any tribunal of any issue in any controversy as to employment relations in three jurisdictions. ${ }^{48}$ Deducting dues not individually authorized is made an unfair labor practice in five jurisdictions. ${ }^{49}$

All of the state labor relations acts, except Connecticut, New York and Rhode Island, contain some so-called "equalizing" provisions which proscribe certain union or employee conduct. The area of proscribed activity is quite limited in Oregon, Puerto Rico, Massachusetts and Michigan; it is somewhat broader in Kansas, Hawaii, Minnesota, Pennsylvania and Utah; and in Colorado and Wisconsin the proscriptions are very broad. Among the union unfair labor practices found in the state acts but not in the federal act are the following: six jurisdictions proscribe breach of contract by a union $;^{50}$ three make it illegal for a union to ignore the final determination of an issue by a competent tribunal ${ }^{51}$ five declare picketing or boycotting or boycotting in the absence of a majority strike to be unlawful; ${ }^{52}$ Puerto Rico makes it an unfair labor practice for a union to "unjustifiably" exclude or suspend from membership an employee in a unit covered by a union security provision; $;^{53}$ and Colorado makes it unlawful for a union to demand or require that any "stand-in" employee be hired..$^{54}$

${ }^{45}$ Colo. Rev. Stat. (1953) $\$ \$ 80-5-6(1)(f), 80-5-6(2)$ (c); Hawaii L. (1945) c. 72A, $\$ 4150.08$ (1)(f), 4150.08(2)(c); Minn. Stat. Ann. (1947) \$179.12(a); Puerto Rico L. Ann. (1954) Title 29 , c. 3, $\S \S 69(1)(\mathrm{f})-69(2)(\mathrm{a})$; Wis. Stat. Ann. (West, 1957) $\$ \$ 111.06(1)(\mathrm{f}), 111.06(2)$ (c).

${ }^{47}$ Hawaii L. (1945) c. 72A, \$4150.08(1)(e); Puerto Rico L. Ann. (1954) Title 29, c. 3 , $\S 69(1)(\mathrm{e})$; Utah Code Ann. (1953) $\$ 34-1-8(1)(\mathrm{e})$; Wis. Stat. Ann. (West, 1957) \$111.06(1)(e)'.

${ }^{48}$ Colo. Rev. Stat. (1953) $\$ 80-5-6(1)(6)$; Hawaii L. (1945) c. 72A, $\$ 4150.08(1)$ (g); Wis. Stat. Ann. (West, 1957) §111.06(1)(g).

${ }^{49}$ Colo. Rev. Stat. (1953) § 80-5-6-1(i); Hawaii L. (1945) c. 72A, $\$ 4150.08(1)$ (i); Kan. Gen. Stat. (1949) $\$ 44809(6)$; Pa. Stat. Ann. (Purdon, 1952) Title 43, §211.6(1)(f); Wis. Stat. Ann. (West, 1957) $\$ 111.06(1)$ (i). Such conduct is also prohibited under the criminal provisions of the Labor Managemen amended by 29 U.S.C.A. $\S 186(\mathrm{c})(4)$ (1956).

${ }^{50}$ Colo. Rev. Stat. (1953) $\S 80-5-6(2)$ (c); Hawaii L. (1945) c. 72A, $\$ 4150.08(2)$ (c); Kan. Gen. Stat. (1949) §44:809(15); Minn. Stat. Ann. (1950) §179.11(1); Puerto Rico L. Ann. (1954) Title 29, c. 3, §69(2)(a); Wis. Stat. Ann. (West, 1957) § 111.06(2)(c).

5I Colo. Rev. Stat. (1953) $\S 80-5-6-2(d)$; Hawaii L. (1945) c. 72A, $\$ 4150.08(2)$ (d); Wis. Stat. Ann. (West, 1957) \$111.06(2)(d).

${ }^{52}$ Hawaii L. (1945) c. 72A, $\$ 4150.08(2)$ (e); Kan. Gen. Stat. (1949) §44:809(3); Minn. Stat. Rev. (1950) § 179.11(8); Utah Code Ann. (1953) §34-1-8(2)(c); Wis. Stat. Ann. (West, 1957) $\$ 111.06(2)(\mathrm{e})$.

${ }^{53}$ Puerto Rico L. Ann. (1954) Title 29, c. 3, § 69(2)(b).

54 Colo. Rev. Stat. (1953) $\S 80-5-6-2(\mathrm{k})$. A somewhat similarly directed federal provision has been given a narrow construction. Labor Management Relations Act, 1947, at $\$ 8(\mathrm{~b})(6)$, 61 Stat. 136, 142 (1947), as amended by 29 U.S.C.A. $\$ \$ 141,158$ (b) (6) (Supp., 1952); Labor Board v. Gamble Enterprises, 345 U.S. 117 (1953); Newspaper Pub. Assn. v. Labor Board, 345 U.S. 100 (1953). 
Every state labor relations act, except Michigan's, establishes a procedure for the holding of representation elections in appropriate units. Only Puerto Rico requires an employer to maintain a neutral position in such elections. ${ }^{55}$ The representation procedure is generally similar to that found in the federal act, though more rudimentary, and is subject to direct judicial review in five states.$^{56}$ Rhode Island does not permit its Board to conduct an election between unions affiliated with the same parent labor organization; $;{ }^{57}$ New York repealed a similar provision this year.

The Supreme Court's decision in the recent Guss case $^{58}$ has now eliminated the area of uncertainty concerning the limits of jurisdiction of state labor boards as against the Federal Board. It now appears that the NLRB's jurisdiction is exclusive over all employers engaged in interstate commerce, whether or not the Board chooses to assert its jurisdiction over a particular employer. ${ }^{59}$ This decision has unquestionably greatly limited the practical importance of the state labor relations acts. It is an irony of history that this relative eclipse of the states from the labor relations field has come largely as a result of the Taft-Hartley Act, the leading proponents of which were vigorous supporters of states' rights.

\section{Picketing}

The years 1937 and 1957 not only encompass the twenty-year period since the enactment in Wisconsin of the first state labor relations act in the United States, but these years and that same state also figure most prominently in the story of picketing in the United States. It was in each of these years that the Court decided two landmark cases, both from Wisconsin, which were to open and close an era of Supreme Court law on the power of a state to regulate peaceful picketing. In 1937 the United States Supreme Court handed down its decision in the Senn case, ${ }^{60}$ which held Wisconsin's little Norris-LaGuardia Act, limiting

${ }^{55}$ Puerto Rico I. Ann. (1954) Title 29, c. 3, $\S 69(1)(\mathrm{g})$. It is quite interesting to note that Puerto Rico, which has been most actively seeking to attact new industries, has not sought to do so by the passage of restrictive labor legislation as has been the case with the southern states.

${ }^{56}$ Colo. Rev. Stat. (1953) $§ 80-5-8(5)$, (8); Pa. Stat. Ann. (Purdon, 1952) Title 43, $\$ 211.9$ (b); Wis. Stat. Ann. (West, 1957) $\$ \S 111.05(3), 111.07(8)$; Ore. Rev. Stat. (1955) $\$ 662.720$. This seems to have also been the practice in Minnesota even though there is no express statutory authority.

${ }^{57}$ R.I.L. (1941) c. $1066, \S 6(3)$.

${ }^{68}$ Guss v. Utah Labor Board, 353 U.S. 1 (1957). See also Bethlehem Co. v. State Board, 330 U.S. 767 (1947).

${ }^{69}$ In Guss v. Utah Labor Board, 353 U.S. 1, 9 (1957), the Supreme Court held that "the proviso to Sec. $10(\mathrm{a})$ is the exclusive means whereby states may be enabled to act concerning the matters which Congress has entrusted to the National Labor Relations Board." The Labor Management Relations Act, 1947, at $\$ 10$ (a) permits the NLRB to cede jurisdiction only to a state whose policy conforms to federal labor policy. Since no state has such a policy, the NLRB is powerless to cede any of its jurisdiction, even over those industries lying in the "no-man's land" beyond the reach of NLRB jurisdictional standards.

${ }^{60}$ Senn v. Tile Layers Union, 301 U.S. 468 (1937). 
the issuance of injunctions in labor disputes, to be constitutional. The Court, in sustaining the right of the Wisconsin legislature to prohibit her state courts from enjoining peaceful picketing in a labor dispute, said:

Members of a union might, without special statutory authorization by a state, make known the facts of a labor dispute, for freedom of speech is guaranteed by the Federal Constitution. ${ }^{61}$

This declaration by the Court in the Senn case soon became the basis for the Thornhill doctrine by which the Court threw the mantle of the First and Fourteenth Amendments around all forms of peaceful picketing "as within the area of free discussion that is guaranteed by the Constitution." ${ }^{\prime 2}$ Elevated to the lofty heights of a constitutionally-protected right, peaceful picketing for a period appeared to enjoy the virtual immunity from state or federal regulation that attaches to freedom of speech under our Bill of Rights.

But by 1957 the Court had "now come full circle"63 since Senn and Thornhill. In Teamsters L'inion v. Vogt, Inc., ${ }^{64}$ the Court permitted Wisconsin to enjoin the peaceful picketing of a small gravel pit by a Teamster local after the union had tried unsuccessfully to induce employees of the pit to join its ranks. The Wisconsin Supreme Court had found that the purpose of the picketing was to coerce the employer to interfere with his employee's right to refuse to join a union, such purpose being unlawful in Wisconsin. The United States Supreme Court had no hesitancy in holding that the lone picket peacefully patrolling outside the gravel pit was not protected in his picketing by the Fourteenth Amendment from state regulation. ${ }^{65}$

As the protection of picketing under the First and Fourteenth Amendments withered away during the two decades, the Court breathed new vitality into another provision of the Constitution-the Supremacy Clause. ${ }^{66}$ Except where the picketing was enmeshed with violence ${ }^{67}$ or the action was for damages under

${ }^{61}$ Id., at $478 . \quad 62$ Thornhill v. Alabama, 310 U.S. 88, 102 (1940).

${ }^{63}$ In Teamsters Union v. Vogt, Inc., 354 U.S. 284 (1957). Justice Douglas, dissenting, concluded: "Today, the Court signs the formal surrender. State courts and state legislatures cannot fashion blanket prohibitions on all picketing. But, for practical purposes, the situa tion now is as it was when Senn v. Tile Layers Union, 301 U.S. 468, was decided. State courts and state legislatures are free to decide whether to permit or suppress any particular line for any reason other than a blanket policy against all picketing. . . " Id., at 297.

64 Ibid.

${ }^{65}$ The opinion in the Vogt case was written by Mr. Justice Frankfurter who in 1941 had written the Court's opinion in AFL v. Swing, 312 U.S. 321 (1911), striking down as unconstitutional an Illinois injunction banning stranger picketing. In his dissent in the Vogt case, Mr. Justice Douglas observed that in the Swing case, "we held that the First Amendment protected organizational picketing on a factual record which cannot be distinguished from the one now before us." Teamsters Union v. Vogt, Inc., 354 U.S. 284, 295-96 (1957).

60 "This Constitution and the Laws of the United States which shall be made in Pursuance thereof . . . shall be the supreme Law of the Land . . . any Thing in the Constitution or Laws of any State to the Contrary notwithstanding. ..."U.S. Const. Art. 6, \$2.

${ }^{67}$ Allen-Bradley Local v. W.E.R.B., 315 U.S 740 (1942); UAIV v. Wisconsin Employment Relations Board, 351 U.S. 266 (1956). 
a common-law remedy, ${ }^{68}$ the power of the federal government over picketing in industries affecting interstate commerce was "plenary,"69 excluding state regulation, even where its own agency declined to assert jurisdiction. ${ }^{70}$

The Wagner Act did not limit picketing. The Taft-Hartley Act prohibits picketing where the activity is part of an illegal course of conduct under the secondary boycott provisions of the Act. ${ }^{71}$ However, regarding picketing in industries engaged in interstate commerce, the Supreme Court has pointed out:

The detailed prescription of a procedure for restraint of specified types of picketing would seem to imply that other picketing is to be free of other methods and sources of restraint. For the policy of the National Labor Management Relations Act is not to condemn all picketing but only that ascertained by its prescribed processes to fall within its prohibitions. Otherwise, it is implicit in the Act that the public interest is served by freedom of labor to use the weapon of picketing. For a state to impinge on the area of labor combat designed to be free is quite as much an obstruction of federal policy as if the state were to declare picketing free for purposes or by methods which the federal Act prohibits. ${ }^{72}$

The effect of Supreme Court decisions relating to peaceful picketing is to make state laws applicable only to those limited intrastate businesses which manage to avoid the broad sweep of the Commerce Clause.

Five jurisdictions permit picketing only if a majority of the employees have voted in favor of a strike. ${ }^{73}$ Thus Wisconsin in 1939, in substituting an Employnent Peace Act for a Baby Wagner Act, declared it to be an unfair labor

${ }^{68}$ United Workers v. Laburnum Corp., 347 U.S. 656 (1954). The question of whether the federal pre-emption doctrine applies to private state actions for damages arising out of alleged interference with the right of the plaintifis to work during a strike is now before the Supreme Court for decision. International Union v. Russell, 264 Ala. 456, 88 So.2d 175 (1956), cert. granted 352 U.S. 915 (1956). The Alabama Supreme Court permitted the jury to assess both actual and punitive damages.

In the appendix to its brief in the Supreme Court, the UAW has collected a partial list of damage suits pending in Alabama against unions growing out of alleged interference with the right of employees to work. There is contained a list of 89 such actions in which aggregate damages of $\$ 2,135,500$ are prayed for. In only three of the law suits is there any allegation of physical assault. Brief for Petitioner, Appendices, Appendix B at pp. 7a-12a.

${ }^{69}$ Guss v. Utah Labor Board, 353 U.S. 1 (1957).

${ }^{70}$ Ibid.; Meat Cutters v. Fairlawn Meats, 353 U.S. 20 (1957).

${ }^{7}$ Labor Management Relations Act, 1947, 61 Stat. 141 (1947), 29 U.S.C.A. $§ 158($ b)(4) (1956).

72 Garner v. Teamsters Union, 346 U.S. 485, 499 (1953).

${ }^{73}$ Colo. Rev. Stat. (1953) § 80-5-6(2) (e); Hawaii L. (1945) c. 72A, $\$ 4150.08$; Kan. Gen. Stat. (1949) $\$ 44-809(3)$; Utah Code Ann. (1953) $\$ 34-1-8(2)$ (c); Wis. Stat. Ann. (West, 1957) $\S 111.06(2)$ (e). In American Federation of Labor v. Reilly, 113 Colo. 90, 155 P.2d 145 (1944), the Colorado statute was held to be inoperative because it is inseparably connected in substance with the unconstitutional requirement of Section 94 (20), for the compulsory incorporation of labor unions. The Texas Supreme Court ruled that the Texas statute is unconstitutional if "labor dispute" is restricted to a controversy between an employer and a majority of his employees. Operating Engineers v. Cox, 148 Tex. 42, 219 S.W.2d 787 (1949). See also Ex parte Henry, 147 Tex. 315, 215 S.W.2d 588 (1948). 
practice for any person "to cooperate in engaging in, promoting or inducing picketing, boycotting or any other overt concomitant of a strike unless a majority in a collective bargaining unit of the employees of an employer against whom such acts are primarily directed have voted by secret ballot to call a strike." 74 In 1943, the Wisconsin legislature, with a long look at the intervening Supreme Court decisions in Thornhill ${ }^{75}$ and Swing, ${ }^{76}$ solemnly added after the word "picketing" in the above sentence: "(not constituting an exercise of constitutionally guaranteed free speech)."77

Stranger picketing has been a frequent subject of state legislative assault, in spite of the Supreme Court decision in the Swing case ${ }^{73}$ holding such activity to be constitutionally protected. Five states have banned picketing by nonemployees, ${ }^{79}$ while an equal number by statute prohibit picketing in the absence of a labor dispute. ${ }^{80}$ Oregon prohibits picketing unless the union is certified as bargaining agent for the employees. ${ }^{81}$

The location of picketing has also been a subject of legislative interest. Picketing of homes has been prohibited in eight jurisdictions. ${ }^{82}$ Picketing of courts has been prohibited in Louisiana and Massachusetts. ${ }^{83}$

The method of picketing has also been subjected to considerable legislative attention. Ten states by statute ban mass picketing, ${ }^{84}$ and seven jurisdictions

"Wis. Stat. Ann. (West, 1957) §111.06(2)(e).

${ }^{75}$ Thornhill v. Alabama, 310 U.S. 88 (1940).

${ }^{76}$ AFL v. Swing, 312 U.S. 321 (1941).

77 Wis. Stat. Ann. (West, 1957) §111.06(2)(e).

78312 U.S. 321 (1941).

${ }^{79}$ Minn. Stat. Ann. (1947) \$179.11(4); N. D. L. (1953) \$34.0912; Pa. Stat. Ann. (Purdon, 1952) Title 43, $\$ 211.6(2)$ (d); S.D. Code (Supp., 1939) §17.1112(5); Va. Code Ann. (1950) $\S 40-64$.

${ }^{80}$ Ariz. Rev. Stat. Ann. (1956) c. 8, §23-1322; Minn. Stat. Ann. (1947) § 179.11(5); S.D. Code (Supp., 1939) §17.1112(1); Tex. Stat. Ann. (Vernon, 1947) Art. 5154d, §4; Wis. Stat. Ann. (West, 1957) § 111.06(2)(g).

81 Ore. Rev. Stat. (1955) $\$ 662.770$.

${ }^{82}$ Conn. Rev. Stat. (1944) c. 424, $\$ 8610$; Fla. Stat. Ann. (1952) Title 29, § 447.09(11); Hawaii L. (Special Session, 1949) c. 273A, §11527; Kan. Stat. Ann. (1949) §44-809(14); Mich. Stat. Ann. (1950) c. 154, $\$ 17.454(10.5)$; S.D. Code (Supp., 1939) $\$ 17.1107$; Utah Code Ann. (1953) §34-1-8(2) (a); Wis. Stat. Ann. (West, 1957) $\$ 111.06(2)$ (a).

${ }^{83}$ La. Stat. Ann. (1950) $\$ 14-401$; Mass. L. Ann. (1956) c. 268, $\$ 13$ A. Even in the absence of statute, the picketing of a judge's home during the pendency of a proceeding has been held to be contempt. Farwick Airflex Co. v. United Electrical R. \& M. Workers, 56 Ohio Abs. 426, 92 N.E.2d 446 (1950).

84 Ark. Stat. Ann. (1947) $\$ 81-207$; Colo. Rev. Stat. (1953) $\$ 80-5-6(2)(f) ;$ Ga. Code Ann. (Supp., 1955) \$ 51-803; Mich. Stat. Ann. (1950) c. 154, \$17.454(10.5); Miss. L. (Session Laws 1942) c. 328, § 2; Neb. Rev. Stat. (Supp., 1943) § 2S-814.01; S.C. Code, (Supp., 1956) c. $21, \$ 40-46.6(2)$; Tex. Stat. Ann. (Vernon, 1947) Art. 5154d; Utah Code Ann. (1953) \$34$1-8(2)$ (d); Wis. Stat. Ann. (West, 1957) $\$ 111.06(2)(\mathrm{f})$. The courts have not been reluctant about prohibiting mass picketing even in the absence of statute. Lodge Mfg. Co. v. Gilbert, 195 Tenn. 403, 260 S.W.2d 154 (1953); Zanesville Publishing Co. v. Typographical Union, 
prohibit picketing which interferes with ingress and egress. ${ }^{85} \mathrm{~A}$ few statutes attempt to define mass picketing. The South Dakota statute defines it as "picketing by a greater number than five per cent of the first one hundred striking or locked out employees of the picketed employer and one per cent of the employees in excess of this number." 86 Mass picketing is defined in Nebraska as "any form of picketing in which there are more than two pickets at any one time within either 50 feet of any entrance to the premises being picketed or within 50 feet of any other picket or pickets, or in which pickets constitute an obstacle to the free ingress and egress to and from the premises being picketed or any other premises either by obstructing by their persons or by the placing of vehicles or other physical obstructions." 87 Picketing is limited to one person per entrance in Minnesota in the absence of a strike. ${ }^{88}$

\section{STRIKES}

The principal basis of federal jurisdiction in the labor field is said to be the avoidance of strikes which otherwise burden or obstruct interstate commerce. ${ }^{89}$ One method for avoiding these obstructions is "by encouraging the practice and procedure of collective bargaining. ..." The Taft-Hartley Act itself, in the course of defining the requirements of collective bargaining, establishes certain mandatory procedures that must be followed in order to terminate or modify an existing collective bargaining agreement, including notice requirements. ${ }^{90}$ It establishes a procedure that may be followed in national emergency strikes, including the appointment by the President of a fact-finding board of inquiry, injunctive relief, and a secret ballot of the employees on the employer's last offer. ${ }^{91}$ For other types of disputes the Federal Mediation and Conciliation

32 CCH Lab. Cas. Tf 70,866 (Ohio C.P., 1956); Schollhorn Co. v. Playthings Union, 10 Lab. Cas. I 63,015 (Conn. C.P., 1946); Warner Bros. Pictures, Inc. v. Painters Local No. 644, $10 \mathrm{CCH}$ Lab. Cas. If 62,843 (Cal. Sup. Ct. 1945); Westinghouse Electric Corp. v. United Electrical Workers, Local 107, $383 \mathrm{~Pa} .297,118$ A.2d 180 (1955).

${ }^{85}$ Fla. Stat. Ann. (1953) Title $29, \S 447.09(13)$; Hawaii L. (Special Session 1949) c. 273A, $\$ 11527$; Kan. Stat. Ann. (1949) §44-809(16); Mich. Stat. Ann. (1950) c. $154 \$ 17.454(10.5)$; S.C. Code (Supp. 1956) c. 21, $\S 40-46.6(2) ;$ S.D. Code (Supp., 1939) § 17.1112(3); Va. Code (1950) Title $4, \S 40-64$.

${ }^{86}$ S.D. Code (Supp., 1939) \$17.1112(5).

${ }^{87}$ Neb. Rev. Stat. (Supp., 1943) § 28-814.02. $\quad{ }^{88}$ Minn. Stat. Ann. (1947) $§ 179.11(5)$.

${ }^{89}$ Labor Management Relations Act, 1947, at $\S 1$, 61 Stat. 136 (1947), 29 U.S.C.A. $\S 151$ (1956).

${ }^{90}$ Id., at $\$ 8$ (d), 61 Stat. 142 (1947), 29 U.S.C.A. $\$ 158($ d) (1956). The Wagner Act contained no provisions concerning dispute settlement and specifically provided: "Nothing in this Act shall be construed so as to interfere with or impede or diminish in any way the right to strike." National Labor Relations Act, 1935, at $\$ 13,49$ Stat. 457 (1935). This language was qualified by the significant clause "except as specifically provided for herein" in the Taft-Hartley Amendments. Labor Management Relations Act, 1947, at $\S 13,61$ Stat. 151 (1947), 29 U.S.C.A. $\S 163$ (1956).

${ }^{91}$ Labor Management Relations Act, 1947, at $\S 206,61$ Stat. 155 (1947), 29 U.S.C.A. $\S \S 176-180$ (1956). 
Service is to "seek to induce the parties voluntarily to seek other means of settling the dispute without resort to strike... including submission to the employees in the bargaining unit of the employer's last offer of settlement for approval or rejection in a secret ballot."92

Between 1940 and 1950 a number of states passed legislation directly related to strikes in the collective bargaining process, including the following major types of legislation:

(1) Ten jurisdictions, ${ }^{93}$ including Michigan, had passed laws making strikes illegal unless approved by a majority vote by secret ballot prior to the walkout. ${ }^{94}$

(2) Eight jurisdictions, ${ }^{95}$ including Michigan, had passed laws requiring some

92 Id., at \$203(c), 61 Stat. 154 (1947), 29 U.S.C.A. \$ 173(c) (1956).

${ }^{93}$ Ala. Code (Supp., 1955) Title 26, $\$ 388$; Colo. Rev. Stat. (1954) Art. 5, c. 80-5-6(2)(e); Fla. Stat. Ann. (1952) \& 447.09(3); Ga. L. (1941) c. 293, $\$ \$ 3$, 4; Hawaii L. (1945) $\$ 4150.08$ (2)(e); Kan. Gen. Stat. Ann. (1949) § 44-809(3); Ky. Rev. Stat. (1946) § 336.150; Mich. Stat. Ann. (1950) § 17.454(10); Minn. Stat. Ann. (1947) § 179.11(8); N.D. L. (1949) $\$ 340.190$; Tex. Civ. Stat. Ann. (Vernon, Supp., 1956) Art. 5154g. \$2; Utah Code Ann. (1953) § 34-1-8 (2)(c); Wis. Stat. Ann. (West, 1957) $\$ 111.06(2)(\mathrm{e})$. The Alabama, Colorado and Kansas acts were held unconstitutional.

94 'The assumption of this type of legislation appears to be that union leaders take employees out on strike against their will, and if given the opportunity to vote, employees would frequently reject such action. In strike votes conducted by the NLRB under the War Labor Disputes Act during the period 1944-1946, a majority opposed strike action in only eleven per cent of the cases. Almost two million valid ballots were cast in all elections combined, somewhat over four-fifths being cast in favor of "an interruption of war production." 11 N.L.R.B. Ann. Rep. 91 (1946). On the basis of a survey of employer opinion in 1945, the Journal of Commerce reported as follows: "The use of taxpayers' money for the purpose of holding elections which are aimed at intimidating employers or the Government is strongly opposed by industrialists. It is felt that if unions wish to strike they can poll their own members, as they have always done before the war." J. of Comm. 1-4 (Oct. 10, 1945). A study shows that 61.4 per cent of union workers are covered by constitutions which require local union strike votes. Of these 20.5 per cent are covered by provisions which require strike votes both before and during the strike. A two-thirds majority was required in about half of the international union constitutions which specified the size of the vote necessary for strike action. Strike-Control Provisions in Union Constitutions, 77 Monthly Lab. Rev. 497, 498 (1954). However, the leading study of union strike votes concluded that "the procedures of local unions for calling strikes are considerably more democratic than reference to their international constitutions would suggest." Parnes, Union Strike Votes 67 (1956). A recent case sustained the right of an employer to insist on a contract clause forbidding strikes unless approved by a majority vote of the employees involved, both union and nonunion. NLRB v. Wooster Division of Borg-Warner Corp., 236 F.2d 898 (C.A. 6th, 1956), cert. granted, 353 U.S. 907 (1957).

Colo. Rev. Stat. (1954) Art. 5, c. 80-5-11(2) (dairy or farm workers); Del. L. (1947) c. 196; Hawaii L. (1945) \&4150.12 (agricultural workers); Mich. Stat. Ann. (1950) \$17.454(9); Minn. Stat. Ann. (1947) § 179.06; Mo. L. (1947) S. 79; N.D.L. (1947) H.B. 160; Wis. Stat. Ann. (West, 1957) \& 111.11 (agricultural workers). The assumption of this type of provision-which might be termed the "hot-head theory" of strikes-appears to be that many strikes are hastily called in an atmosphere of crisis, and that a legally required period of status quo between the the decision to strike and the actual strike will result in a settlement of the dispute or a "cooling-off' of the desire to strike. In effect, a sixty day cooling off period is imposed by the notice requirements of Section 8 (d) of the federal act in connection with collective bargaining disputes. Labor Management Relations Act, 1947, at $\$ 8$ (d)(1), 61 Stat. 142 (1947), 29 U.S.C.A. $\S 158(d)(1)(1956)$. International union approval to strike is directly required in union con- 
type of notice and a cooling-off period before a strike could be legally called. Then on May 8, 1950, the United States Supreme Court in .1 utomobile Workers 2. $O^{\prime} B$ rien,${ }^{96}$ held the Michigan law requiring a 20 day strike notice and majority authorization of a strike invalid as applied to an industry engaged in interstate commerce. Referring to the provisions of the Taft-Hartley Act the Court said, "None of these sections can be read as permitting concurrent state regulation of peaceful strikes for higher wages. Congress occupied this field and closed it to state regulation "97 This was soon followed by the decision in Bus Employees v. Wisconsin Board..$^{98}$ The Court there held invalid, as applied to a public utility within the jurisdiction of the National Labor Relations Act, the Wisconsin law which prohibited strikes and lockouts in public utilities and required compulsory arbitration. The effect of these decisions was to make clear that the states cannot regulate the calling or the settlement of strikes in industries affecting commerce but must confine their jurisdiction solely to intrastate business. An exception, however, is provided where the activity is neither prohibited nor protected by the Taft-Hartley Act, as, for example, recurrent, unannounced work stoppages. ${ }^{99}$ The principal responsibility for dealing with the $33,000,000$ man-days of strike idleness annually in the United States ${ }^{100}$ unmistakably belonged to the federal government.

As far as intrastate industry was concerned, a glance at the state laws in effect at the end of the 1957 legislative sessions reveals that during the interval between the decision in the O'Brien case in 1950 and the present time, no additional states have adopted a strike vote requirement, ${ }^{101}$ while three of the eleven which had such statutory provisions in 1950 subsequently repealed them..$^{102}$

Of the eight laws in effect at the time of the O'Brien decision, requiring notice before a strike is called, two states-Kentucky and Minnesota-have since repealed such a requirement, and no other state has added such a provision.

Eleven jurisdictions ${ }^{103}$ had laws regulating strikes in public utilities at the

stitutions covering $\mathbf{5 9 . 4}$ per cent of organized workers and indirectly required in constitutions covering an additional 29.1 per cent, or a total of 88.5 per cent. Strike-Control Provisions in Union Constitutions, 77 Monthly Lab. Rev. 497, 498 (1954).

${ }^{96} 339$ U.S. 454 (1950). $\quad{ }^{97}$ Id., at $457 . \quad 98340$ U.S. 383 (1951).

${ }^{99}$ Auto Workers v. Wis. Board, 336 U.S. 245 (1949).

${ }^{100}$ Herlihy and Moede, Analysis of Work Stoppages During 1956, 80 Monthly Lab. Rev. 565,568 (1957).

${ }^{101}$ In 1955 Kansas enacted a strike vote requirement to replace its earlier law held unconstitutional in Stapleton v. Mitchell, 60 F. Supp. 51 (D.C. Kan., 1945). Kan. L. (1955) c. 252, $\S 3(3)$.

10247 Del. L. (1948) c. 301, at 662, repealing 46 Del. L. (1948) c. 496; Mo. L. (1949) H.B. 20 , § 1, pp. 315-16, repealing Mo. L. (1947), S.B. $79, \S 3$, p. 351; N.D.L. (1953) c. $216, \S 8$, repealing N.D.L. (1949) Referred Measure of H.B. 160, pp. 511-12.

${ }^{103}$ Florida, Hawaii, Indiana, Maryland, Massachusetts, Michigan, Missouri, Nebraska, New Jersey, Pennsylvania and Texas. 
time of the Supreme Court's decision in 1951 in the Bus Employees case. ${ }^{104}$ None of these statutes has been repealed, and Virginia, in 1952, ${ }^{105}$ and Maryland, in $1956,{ }^{106}$ added comparable statutes. Neither the Maryland nor the Virginia law contains a ban on strikes until the procedures provided for by law have been exhausted. Such a ban is contained in four of the earlier statutes. ${ }^{107}$ Seven of the laws provide for seizure of the utility by the state (the seizure provision in Virginia applies only to coal mines). ${ }^{108}$ Three states expressly ban strikes after seizure. ${ }^{109}$ Under the Maryland law the Governor operated the plant or facility "for the account of the person operating it immediately prior to the seizure," except that by filing written notice with the Governor within 10 days after seizure, the owner may elect "to receive in lieu thereof fair and reasonable compensation for the appropriation and temporary use of his property...."110 In fixing the fair value the effect of the threatened interruption from the labor dispute on the value to the owner shall be taken into account..11 Ten of the state laws provide for compulsory mediation, ${ }^{112}$ while nine make provision for compulsory arbitration. ${ }^{113}$ In eight of the states the law applies only

104 Bus Employees v. Wisconsin Board, 340 U.S. 383 (1951); Ibid., 340 U.S. 416 (1951) (connected case). The Kansas statute providing for compulsory arbitration of labor disputes in certain industries "affected with a public interest" is not included in view of the United States Supreme Court decision in Wolff Packing Co. v. Court of Industrial Relations, 267 U.S. 552 (1924), holding vital parts of the statute unconstitutional.

${ }^{105}$ The Virginia Statute expressly states, "In event federal legislation does not apply ... it shall be the duty of the utility and its employees, or designated representatives, to meet and confer with the Commissioner...." Va. Acts (1952) c. 697, §40-75.3. Hawaii, which already had an act covering public utilities, passed an act in 1951 providing for the seizure and operation of the plant and facilities of stevedoring companies during emergencies. Hawaii L. (1951) c. 73A, $\$ 4181.01(12)$.

${ }^{106}$ The Maryland statute by its own terms expired this year. MId. L. (1956) c. 41, $\S 5$.

${ }^{107}$ Fla. Stat. Ann. (1952) Title 29, $\$ 453.05$; Ind. Stat. Ann. (Burns, 1952) $\$ 40-2406$; Mich. Stat. Ann. (1951) c. 154, $\$ 17.454(14.8) ;$ Pa. Stat. Ann. (Purdon, 1952) Title 43, $\$ 213.6$.

${ }^{108}$ Hawaii L. (1945) $\S 4161 ;$ Kan. Gen. Stat. Ann. (1950) §44-620; Md. Ann. Code (1957) Art. 89, § 12G; Mass. Ann. L. (1950) c. 150B, \$4(B)(1); Mo. Rev. Stat. (1952) § 295.180; N.J. Rev. Stat. (1940) §34:13B-13 (Supp., 1956); and N.D. Rev. Code (1944) §37-0106.

${ }^{\text {In }}$ Mass. Ann. L. (1950) c. 150B, $\S 4(B)$; Mo. Rev. Stat. (1952) $\S 295.200$; and N.J. Rev. Stat. (1940) §34:13B-19 (Supp., 1956).

sro Md. L. (1956) c. 41, § 1, 12G(1).

" Ibid.

12 Fla. Stat. Ann. (1952) Title 29, $\S 453.04$; Ind. Stat. Ann. (Burns, 1952) c. 24, $\S \S 40-2405$ to 40-2406; Kan. Gen.Stat. Ann. (1950) $\$ \$ 44-606$ to 44-616; Mass. Ann. L. (1950) c. 150B, $\$ 3$ (A); Minn. Stat. (1947) § 197.06; Mo. Rev. Stat. (Vernon, 1952) §\$295.030, 295.080; N.J. Rev. Stat. (1940) $\$ \S 34: 13 A-4,5,6$ (Supp., 1956); N.D. Rev. Code (1943) $\$ \S 34-1001$ et seq. (Supp., 1953); Pa. Stat. Ann. (Purdon, 1952) Title 43, §213.5; and Va. Code (1950) § 40-95.3.

113 Fla. Stat. Ann. (1952) Title 29, $\S 453.06$; Ind. Stat. Ann. (Burns, 1952) c. $24, \S \S 40-2407$ et seq.; Kan. Gen. Stat. Ann. (1950) $\$ \$ 44-606$ to 44-616; Minn. Stat. (1947) $\$$ 179.07-179.08; Mo. Rev. Stat. (Vernon, 1952) § 295.160; Neb. Rev. Stat. (1952) § 48-810; N.J. Stat. Ann. (1940) $\S 3$ 34:13B-20 to 34:13B-23 (Supp., 1956); Pa. Stat. Ann. (Purdon, 1952) Title 43, $\S 213.8$; Wis. Stat. Ann. (West, 1957) $\$ \S 111.57-111.60$. 
to public utilities, ${ }^{114}$ while the North Dakota statute, which does not provide for compulsory arbitration, applies to any labor dispute "likely to cause a strike or lockout or interferes or is likely to interfere with the due and ordinary course of business or menaces the public peace or jeopardizes the welfare of the community and the parties thereto are unable to adjust the same. . ."115 Hospitals are expressly covered in the Minnesota and Michigan laws, ${ }^{116}$ the stevedoring industry in Hawaii, ${ }^{117}$ and the distribution of food, fuel, hospital and medical services in Massachusetts. ${ }^{118}$ Ten jurisdictions expressly prohibit strikes in government service. ${ }^{119}$

The sit-down strike, which the Supreme Court once characterized as "a high handed proceeding without shadow of legal right," 120 is now expressly prohibited in twelve states. ${ }^{121}$ Since the sit-down strike is neither expressly prohibited nor sanctioned by the Labor Management Relations Act of 1947, ${ }^{122}$ and since the protection of private property rights has traditionally been within the police and equity power of the state, ${ }^{123}$ the right of states effectively to legislate in this area seems clear.

Similarly, the right of the states to enact anti-violence statutes, prohibiting coercive tactics in connection with strikes, is now well established, whether by exercise of the traditional police and equity powers, or through the medium of

$" 4$ Fla. Stat. Ann. (1952) Title 29, $\$ \S 453.04$ et seq.; Ind. Stat. Ann. (Burns, 1952) $\S \S 40-$ 2401 et seq.; Mo. Stat. Ann. (1952) \$295.010; Neb. Rev. Stat. (1952) § 48-802; N.J. Stat. Ann. (1940) § 34:13B-1 (Supp., 1956); Pa. Stat. Ann. (Purdon, 1952) Title 43, § 213-1; Tex. Civ. Stat. (Vernon, 1947) Art. 5154c, § 3; Wis. Stat. Ann. (West, 1957) §111.50. The Maryland provision is no longer applicable, see note 106 supra.

${ }^{115}$ N.D. Rev. Code (1944) § 34-1002 (Supp., 1953). Another North Dakota statute permits the Governor as Commander-in-Chief of the military forces of the state to commandeer any coal mine or public utility in the event of serious labor dispute.

${ }^{136}$ Minn. L. (1941) c. 469, § 4254-27; Mich. Pub. Acts (1949) No. 230, §423.9a.

${ }^{17}$ Hawaii L. (1951) c. 73A, §4181.01(12).

118 Mass. Ann. L. (1950) c. 150B, § 2.

${ }^{119}$ Hawaii, Michigan, Missouri, Nebraska, New York, Ohio, Pennsylvania, Texas, Virginia and Wisconsin. Section 305 of the Taft-Hartley Act prohibits strikes by federal employees. The Wagner Act did not contain such a provision. The constitutionality of a state law forbidding public employees from joining a labor union remains unresolved, the Supreme Court having declined to pass on the issue in a recent case. Government Employees v. Windsor, 353 U.S. 905 (1957). See also Hickman v. Mobile, $256 \mathrm{Ala}$. 141, 53 So.2d 752 (1951); CIO v. Dallas, 198 S.W.2d 143 (Tex. Civ. App., 1946), and the decisions below in the Windsor case, 262 Ala. 285, 78 So.2d 646 (1955); 146 F. Supp. 214 (N.D. Ala., 1956).

${ }^{120}$ NLRB v. Fansteel Metallurgical Corp., 306 U.S. 210, 252 (1939).

121 Colo. Stat. Ann. (1953) § 80-5-6(i); Fla. Stat. Ann. (1949) $§ 447.09(9)$; Kan. Stat. Ann. (1949) §44-809(3); Mich. Pub. Acts (1949) No. 230, §423.15(15); Mass. Stat. Ann. (1949) c. $150 \mathrm{~A}, \S 4 \mathrm{~A}(1)$; Md. Stat. Ann. (1941) c. 340, § 27; Minn. Stat. Ann. (1947) § 179.11(3); Pa. Stat. Ann. (Purdon, 1952) Title 43, § 211.6(b); Utah Code Ann. (1953) § 34-1-8(2)(f); Wash. Rev. Code (1951) $\$ 9.05 .070$; Wis. Stat. Ann. (1957) $\$ 111.06(2)(h)$; Vt. Pub. Acts (1937) No. 210.

122 Cf. note 99 supra. ${ }^{123}$ See note 67 supra. 
a state labor relations board. ${ }^{24}$ Over the years there has been no love lost in this country between the union member and the nonmember, and the latter has been frequently singled out for special legislative protection. The extent of such protection can be discerned from the following Nebraska statute:

It shall be unlawful for any person or persons, singly or by conspiring together, to interfere, or to attempt to interfere, with any other person in the exercise of his or her lawful right to work, or right to enter upon or pursue any lawful employment he or she may desire, by doing any of the following acts: (1) using profane, insulting, indecent, offensive, annoying, abusive or threatening language toward such person or any member of his or her immediate family, or in his, her or their presence or hearing, for the purpose of inducing or influencing, or attempting to induce or influence, such person to quit his or her employment, or to refrain from seeking or freely entering into employment, or by persisting in talking to or communicating in any manner with such person or members of his or her immediate family against his, her or their will, for such purpose; (2) following or intercepting such person from or to his work, from or to his home or lodging, or about the city, against the will of such person for such purpose; (3) photographing such person against his will; (4) menacing, threatening, coercing, intimidating, or frightening, in any manner, such person for such purpose; (5) committing an assault or assault and battery upon such person for such purpose; or (6) loitering about, picketing or patrolling the place of work or residence of such person, or any street, alley, road, highway, or any other place, where such person may be, or in the vicinity thereof, for such purpose, against the will of such person. ${ }^{125}$

Eleven jurisdictions have made coercion of employees by unions an unfair labor practice. ${ }^{126}$

\section{UnION-Security Provisions}

Of all the state legislation enacted in the two decades since 1937, the most bitterly controversial has been in the field of union security.

The Wagner Act permitted any type of union-security provision. ${ }^{127}$ While outlawing the closed-shop contract, the Taft-Hartley Act permits the parties to a collective bargaining agreement to require union membership as a condition of employment after a thirty-day period "following the beginning of such employment or the effective date of such agreement, whichever is later. . . "128

124 Ibid.

${ }^{125}$ Neb. Stat. (1943) Art. 7, \$ 28-812.

${ }^{126}$ Colo. Rev. Stat. (1953) Art. 5, $\$ 80-5-6(2)$ (b); Hawaii L. (1945) c. 72 A, $\$ 4150.08$ (2)(a); Kan. Gen. Stat. Ann. (1949) $\$ 44-809(14)$; Mass. Ann. L. (1949) c. 150A, $\$ 4$ A(2)(c); Mich. Comp. L. (1948) §423.17; Minn. Stat. Ann. (1947) §179.11(7); Ore. Rev. Stat. (1953) $\$ 662.750$; Pa. Stat. Ann. (Purdon, 1952) Title 43, $\$ 211.6(2)(6)$; Puerto Rico L. (1948) Art. $130, \$ \$(2)(c)$; Wash. Code Ann. (1953) $\$ 34-1-8(2)$ (a); Wis. Stat. (1947) $\$ 111.06(2)(a)$.

${ }^{127}$ National Labor Relations Act, 1935, 49 Stat. 452 (1935).

${ }^{128}$ Labor Management Relations Act, 1947, at $\$ 8(a)(3), 61$ Stat. 140 (1947), 29 U.S.C.A. $\$ 158(a)(3)$ (1956). A study in 1954, by the Bureau of Labor Statistics, of 1,716 collective bargaining agreements covering $7,404,600$ workers showed that four out of five of the agreements contained some type of union-security provision, of which almost two-thirds provided for the union shop. Theodore, Union Security Provisions in Agreements, 1954, 78 Monthly Lab. Rev. 649,651 (1955). 
The impetus to state regulation in this field arose from the provision of Section 14(b) which reads: "Nothing in this Act shall be construed as authorizing the execution or application of agreements requiring membership in a labor organization as a condition of employment in any State or Territory in which such execution or application is prohibited by State or Territorial Law." ${ }_{129}$

There are three types of state statutes in the union-security field, of which the most popular is the so-called "right-to-work" law.

Indiana in 1957 became the nineteenth state-and the first major industrial state-to pass such a law. ${ }^{130}$ The Indiana law begins: "It is hereby declared to be the public policy of the State of Indiana that membership or non-membership in a labor organization should not be made a condition to the right to work or to become an employee of or to continue in the employment of any employer." ${ }^{131}$ All of these statutes implement this policy by outlawing agreements requiring membership as a condition of employment.

The Louisiana law, formerly a general right-to-work law, applies now only to agricultural workers. ${ }^{132}$ In Kansas, where a right-to-work bill was vetoed by the Governor in 1955, a resolution for a referendum in 1958 on a right-to-work amendment to the state constitution was just adopted with the required twothirds majority. ${ }^{133}$ Similar referendums have failed to carry in California,

${ }^{129}$ Labor Management Relations Act, 1947, at $\$ 14$ (b), 61 Stat. 151 (1947), 29 U.S.C.A. $\$ 164(\mathrm{~b})$ (1956). The language "State or Territorial Law" has been held not to encompass the political subdivisions thereof, such as a county. Accordingly, the field having been preempted by the federal and state governments, an attempted right-to-work ordinance is void. Chavez v. Sargent, 40 L.R.R.M. 2553 (Cal. Sup. Ct., 1957).

${ }^{130}$ Ala. Code (1940) Title 26, $\$ 375$ (Supp., 1955); Ariz. Rev. Stat. Ann. (1956) § 23-1302; Ark. Const. Amend. 34; Fla. Const. $\$ 12$; Ga. I. (1947) Act 140; Iowa Code (1954) $\$ 7361.1$; La. Rev. Stat. Title 23, \$ 881 (Supp., 1956); Miss. Code Ann. Title 25, § 6984.5 (Supp., 1956); Neb. Const. Art. 15, $\$ \S 13-15$; Nev. Rev. Stat. (1957) $\$ 613.230 ;$ N.C. Code (1950) $\$ \S 95-78$ and 95-84; N.D. Rev. Code (1943) \$34-0114 (Supp., 1949); S.C. Code c. 21, $\$ 40-46$ (Supp., 1956); S.D. Const. Art. VI, $\$ 2$; Tenn. Code (1932) $\$ 11412.8$; Tex. Rev. Civ. Stat. (Vernon, 1947) $\$ 5207 a$; Utah Code Ann. $\$ \S 34-16-1$ to $34-16-18$ (Supp., 1955); Va. Code (1950) $\$ \S 40-68$ to 40-74. The United States Supreme Court has upheld the constitutionality of state right-towork laws. Lincoln Federal Labor Union v. Northwestern Iron \& Metal Co., 335 U.S. 525 (1949). It has also held that peaceful picketing to force a violation of a state right-to-work law may be enjoined by a state court. Local Union 10 v. Graham, 345 U.S. 192 (1952). But see International Brotherhood of Electrical Workers v. Farnsworth, 353 U.S. 969 (1957), reversing a Tennessee state court decision affirming an injunction against peaceful picketing found violative of the state right-to-work law, citing two pre-emption cases.

131 Ind. L. (1957) c. 19, §§ 1-8.

${ }^{132}$ La. Rev. Stat. Title 23, $\$ 881$ (Supp., 1956).

${ }^{133}$ States having right-to-work provisions in their constitutions are Arkansas (Const. Amend. 34); Arizona (Const. Art. 25); Florida (Declaration of Rights $\S 12$ ); Nebraska (Const. Art. $15, \S \S 13-15$ ); and South Dakota (Const. Art. 6, $\$ 2$ ). But even a right-to-work provision in a state constitution is not operative where it contravenes an Act of Congress exercised under the Commerce Clause. Railway Employes' Dept. v. Hanson, 351 U.S. 225 (1956). A means tor evading this decision can be seen in Looper v. Georgia Southern \& Florida Ry., 40 L.R.R.M. 2262 (Ga. Sup. Ct., 1957). 
Maine, New Hampshire, New Mexico and Washington, ${ }^{134}$ while a referendum in Idaho on a "right-to-work initiative proposal" which did carry was held defective because the title failed to refer to union membership. ${ }^{135}$ Enforcement of the various right-to-work laws is secured by a variety of means including criminal sanctions, with provision for fines and sometimes imprisonment, by injunction, or by an action for damages, sometimes including attorney's fees. The Attorney General of North Dakota rendered an opinion on January 13, 1956 , that an agency shop agreement, which does not require membership in the union but does require payment to the union in lieu of membership of "an amount equal to dues collected regular members for the services and benefits he receives under the terms of this agreement," is not violative of the right-towork law, though discharge cannot be secured if the employee refuses to make such payment. ${ }^{136}$ Even though many of the right-to-work laws purport to outlaw the requirement of membership in a union as a condition of employment, an attempt to enforce such a right has not met with success. ${ }^{137}$

A second type of statute, while not prohibiting all union-security provisions, permits such agreements only where they have been authorized by a vote among the covered employees. Colorado, Kansas and Hawaii have followed Wisconsin in adopting such provisions. The required percentage for ratification is now three-fourths of those participating in Colorado and Hawaii, two-thirds in Wisconsin (providing it constitutes a majority of all those in the bargaining unit), and a simple majority in Kansas. ${ }^{138}$ A law of this type was repealed in New Hampshire after the state supreme court had held that as affecting industries engaged in interstate commerce, the union-shop authorization provision of the state law was superseded by the Taft-Hartley Act. The court reasoned that section 14(b) of the Taft-Hartley Act requires that state "prohibitions" of union security agreements take precedence over the federal provisions, but that

\footnotetext{
134 The union-shop authorization elections conducted by the Board under the Taft-Hartley Act, prior to the Taft-Humphrey Amendment in 1951, P.L. 189, 82d Cong., 1st Sess., demonstrated the general popularity of union shop provisions with workers. Unions were authorized by employees to negotiate such provisions in approximately 97 per cent of 44,587 union-shop authorization elections held by the Board, causing President Truman to note in signing the Taft-Humphrey Bill: "In practically every election, the employees have confirmed their desire for the union-shop agreement." Union Security Amendments to the Taft-Hartley Act, 73 Monthly Lab. Rev. 682 (1951).

${ }^{135}$ In re petition of Idaho State Federation of Labor (AFL), 75 Idaho, 367, 272 P.2d 707 (1954). Another initiative referendum is being proposed in Idaho following defeat of right-towork legislation in the recent legislative session. If successful, the proposal would be submitted to the voters in November, 1958. 40 L.R.R.M. 349 (1957).

${ }^{136}$ Accord: [1952] Ops. Nev. Att'y Gen. 184. Contra: [1952] Ops. N.C. Att'y Gen. The North Carolina law explicitly prohibits such payments.

${ }^{137}$ Rabertson v. Limestone Mfg. Co., 40 L.R.R.M. 2522 (W.D.S.C., 1957).

Iss Colo. Rev. Stat. (1953) $\$ 80-5-6(1)$ (c); Wis. Stat. Ann. (West, 1957) Title 13, 111.06 (c)(1); Kan. Gen. Stat. (1949) \& 41-809(4).
} 
the section does not give precedence to state "regulation" of such agreements. ${ }^{139}$ This argument was later rejected by the United States Supreme Court in reviewing the Wisconsin statute. ${ }^{140}$ The legal right to maintain a union shop is sometimes made conditional upon another factor. The Wisconsin statute provides: "The Board shall declare any such all-union agreement terminated whenever it finds that the labor organization has unreasonably refused to receive as a member any employee of such employer."141 Pennsylvania permits a union security contract only "if such labor organization does not deny membership in its organization to a person or persons who are employees of the employer at the time of the making of such agreement."142 The Puerto Rico Labor Relations Board can order temporary suspension or permanent termination of the union-security provision if the union is found to have unjustifiably excluded or suspended anyone from membership. ${ }^{143}$

A third method of treatment of union-security clauses is found in Maryland where they are declared to be against public policy and are, hence, unenforceable. ${ }^{144}$ Execution of a union-security contract in Texas is a violation of the state anti-trust law. ${ }^{145}$

\section{CheckofF}

The Labor Management Relations Act of 1947 permits a checkoff ${ }^{146}$ only upon written authorization of the individual employee. The authorization may be irrevocable for a maximum of one year, or the duration of the agreement,

${ }^{139}$ International Brotherhood of Teamsters v. Riley, 95 N.H. 162, 59 A.2d 476 (1948), rev'd on other grounds, 336 U.S. 930 (1949). The National Labor Relations Board has accepted this distinction. See Cyclone Sales, Inc., 115 N.L.R.B. 431 (1956), where "the Board held that State laws which regulate union-shop agreements, as distinguished from those which prohibit such agreements, are subordinate to the national law and are not encompassed in Section 14(b) of the Act." Id., at 432.

${ }^{140}$ Algoma Plywood Co. v. Wisconsin Board, 336 U.S. 301, 314 (1949).

${ }^{141}$ Wis. Stat. (1939) c. $57, \S 111.06$ (c)(1), amended by Wis. Stat. (1943) c. 465 and by Wis. Stat. (1945) c. 424.

${ }_{142} \mathrm{~Pa}$. Stat. Ann. (Purdon, 1952) Title 43, \$211.6(c). An employee in Massachusetts can be discharged only if ineligible for membership because of occupational disqualification or breach of discipline. Mass. Ann. L. (1937) c. 436, $\$ 7$, amended by Mass. Ann. L. (1956) c. $150 \mathrm{~A}, \S 4(3)$.

${ }^{143}$ Puerto Rico L. Ann. (1945) Act 130, amended by Puerto Rico L. Ann. (1946) Act 6. A similar provision is found in Colorado. Colo. Stat. Ann. (1943) $\$ 94(6)(1)(c)$.

${ }_{144}$ MId. Stat. Ann. (1939) Art. 100, $\$ 64$. A union that enjoys a closed-shop contract cannot practice unreasonable membership restriction in California. James v. Marinship Corp., 25 Cal. 2d 721, 155 P.2d 329 (1945).

${ }^{145}$ Union Security Act, Tex. Stat. Ann. (Vernon, 1956) Title 126, Art. 7428-1. Texas also has a right-to-work law. Tex. Rev. Civ. Stat. (Vernon, 1947) §5207a.

${ }^{146}$ Checkoff is a method of dues collection under which the employer agrees to deduct from the employee's pay his union dues, and in some instances, initiation fees, fines, and assessments, for periodic transmittal of the monies to the union, usually pursuant to a provision in a collective bargaining agreement. The Wagner Act contained no provision relating to checkoff. 
whichever is shorter. ${ }^{147}$ In practice the checkoff authorization usually incorporates an automatic renewal clause with an escape period. ${ }^{48}$ Since the vast majority of collective bargaining agreements ${ }^{149}$ contain provisions for some type of checkoff, ${ }^{150}$ the impact of legislative regulation is of considerable importance.

The Utah Supreme Court in 1951 held that by enacting Section 302, "Congress has effectively preempted the entire field of legislation in regard to the 'check-off' and thus has precluded the States from legislating on that subject."'151

Laws in fifteen jurisdictions require the written authorization of individual employees for checkoff. ${ }^{152}$ Three require that the checkoff must be terminable at will, ${ }^{153}$ while three others require that they must be terminable on thirty day

${ }^{147}$ Labor Management Relations Act, 1947, at $\$ 302$ (c), 61 Stat. 157 (1947), 29 U.S.C.A. $\$ 186(c)$ (4) (1956). See opinion of the Assistant Attorney General, 22 L.R.R.M. 46 (1948). However, the NLRB has held that an employee cannot be discharged under $\$ 8(\mathrm{a})$ (3) for nonpayment of an assessment. International Harvester Co., 95 N.L.R.B. 730 (1951). The NLRB is not involved in the administration of $\$ 302$ (c) which is a criminal provision. See Salant \& Salant, Inc., 88 N.L.R.B. 816 (1950); Crown Products Co., 99 N.L.R.B. 602 (1952). The effect of $\$ 302$ (c) is to outlaw the compulsory or "automatic checkoff" provision which in 1946 covered more than 3,000,000 workers. Extent of Collective Bargaining and Union Recognition, 64 MIonthly Lab. Rev. 765, 768 (1946).

${ }^{148}$ Such a provision has been held to be legal under $\$ 302$ (c). See Opinion of the Assistant Attorney General of the Department of Justice, 22 L.R.R.M. 46 (1948).

${ }^{149}$ A bout three-fourths of the contracts studied by the Bureau of Labor Statistics in 1954 contained checkoff provisions. Theodore, Union-Security Provisions in Agreements, 1954, 78 Monthly Lab. Rev. 649, 651 (1955). A comparison of these findings with an earlier study shows that between 1946 and 1954 the number of workers covered by checkoff provisions doubled. Id., at 658 .

${ }^{160}$ Dues were stipulated as the sole deduction in over one-fourth of the agreements with checkoff; dues and initiation fees in approximately one-fourth; dues, initiation fees, and assessments in less than one-fifth; checlioff of fines was provided for in only 1.5 per cent of the 1,716 agreements studied. Id., at 657.

${ }^{151}$ State v. Montgomery Ward \& Co., 120 Utah 294, 233 P.2d 685 (1951). Two Rhode Island cases hold that the field of checkoff is not pre-empted by Taft-Hartley, Shine v. John Hancock Mutual Life Ins. Co., 76 R.I. 71, 68 A.2d 379 (1949); Chabot v. Prudential Insurance Co. of America, 77 R.I. 396, 75 A.2d 317 (1950), but these decisions are based entirely on the question of whether checkoff is a mandatory subject for collective bargaining under $\S 9$ (a) of the National Labor Relations Act to the complete exclusion of the question of whether $\S 302$ (c) has preempted the field. The Utah court correctly saw the latter as the crux of the issue. The rationale of the Rhode Island court appears questionable since the checkoff if not mandatory is at least a permissible subject for collective bargaining, NLRB v. Reed \& Prince Mfg. Co., 205 F.2d 131 (C.A. 1st, 1953), cert. denied, 346 U.S. 887 (1953), and that which is permissible under the Taft-Hartley Act is pre-empted from the states. Mine Workers v. Arkansas Flooring Co., 351 U.S. 62 (1956). However, the Attorney General of Iowa issued an opinion on September 16,1955 , in which he followed the Rhode Island court and ruled that the federal government had not pre-empted the field of checkoff from state regulation; that the Iowa checkoff law was applicable to interstate as well as intrastate employers in Iowa.

${ }^{152}$ Arkansas, Colorado, Georgia, Hawaii, Indiana, Iowa, Kansas, Kentucky, Massachusetts, Minnesota, Pennsylvania, South Carolina, Texas, Utah, and Wisconsin.

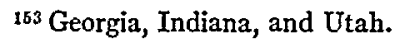


notice. ${ }^{154}$ Iowa requires that the checkoff authorization be countersigned by the spouse. ${ }^{155}$ In Pennsylvania the checkoff must be authorized by majority vote, ${ }^{156}$ while in Rhode Island the employer must allow a checkoff where a majority of his employees request it in writing. ${ }^{167}$

\section{Secondary Boycotts and JuRisdictional Disputes}

The general rule at common law was that secondary boycotts ${ }^{158}$ were unlawful though in some situations they were considered legal. ${ }^{159}$ The Wagner Act contained no prohibitions on union conduct. When the National Labor Relations Act was amended in 1947, however, Congress added Section 8(b)(4)(A), the effect of which provision was described by Senator Robert A. Taft in this way: "This provision makes it unlawful to resort to a secondary boycott to injure the business of a third person who is wholly unconcerned in a disagreement between the employer and his employees." 160 In 1956 the Supreme Court made clear that in view of Section 8(b)(4)(A), a state was now without jurisdiction over all cases of secondary or primary boycotts in any industry affecting interstate commerce. ${ }^{161}$

Secondary boycotts have been subjected to legislative attack in fourteen states. ${ }^{162}$ The majority-the so-called "hot cargo" statutes-make it unlawful for persons not directly involved in the labor dispute to refuse to handle or work on non-union-made materials or supplies. Other statutes are broader, covering all types of secondary boycott. All forms of secondary picketing become illegal in those six states which permit picketing only if there exists a labor dispute between the particular employer and a majority of his employees. ${ }^{163}$ The secondary boycott provision of the Kansas law is somewhat similar to the Taft-Hartley provision except that it extends special protection

${ }^{154}$ Colorado, Iowa, and Wisconsin. In Kansas the checkoff must be terminable at the end of any year of the authorization order upon thirty day written notice.

${ }^{155}$ Iowa Code Ann. (1950) c. $539, \$ 539.4$.

166 Pa. Stat. Ann. (Purdon, 1952) c. 7, \$211.6.

${ }^{167}$ S.253, L. 1950, amended by H.B. 738, L. 1954.

${ }^{158} \mathrm{~A}$ secondary boycott has been defined as "the refusal by one party to deal with another unless such other will, in turn, refuse to deal with a third-the real object of the first party's animus." Gregory, Labor and the Law 34 (1949).

${ }^{169}$ Anderson Sons v. Teamsters, 156 Ohio St. 541, 104 N.E.2d 22 (1952); Iron Moulders' Union v. Allis-Chalmers Co., 166 Fed. 45 (C.A. 7th, 1908).

16093 Cong. Rec. 4198 (1947).

161 Elle Construction Co. v. Pocatello Building and Trades Council, 352 U.S. 884 (1956), rev'g 77 Idaho 514, 297 P.2d 519 (1956). The United States Supreme Court cited Weber v. Anheuser-Busch, 348 U.S. 468 (1955), holding that state courts do not have jurisdiction over conduct either prohibited or protected by the Labor Management Relations Act of 1947.

${ }^{162}$ Alabama, Arizona, California, Colorado, Georgia, Idaho, Iowa, Kansas, Massachusetts, Minnesota, North Dakota, Oregon, Texas, and Utah.

${ }^{163}$ Statutes cited note 80 supra. 
to firms dealing in livestock, farm or dairy products. ${ }^{164}$ Where a struck employer subcontracts or farms out work, it permits the labor organization to carry on any legitimate labor union activity, including picketing, against the other company which is then considered to be directly involved in the dispute. ${ }^{165}$

Jurisdictional disputes involve a controversy between two or more labor organizations regarding control over particular work. ${ }^{166}$ The Labor Management Relations Act of 1947 makes it an unfair labor practice for a union to engage in a strike to force an employer "to assign particular work to employees in a particular labor organization," "167 requires the Board in such cases to seek injunctive relief, ${ }^{16 \$}$ directs the Board "to hear and determine the dispute out of which such unfair labor practice shall have arisen," 169 and permits damage actions to be brought in federal court. ${ }^{170}$ It can hardly be questioned that with such statutory provisions, the federal government has occupied the field of jurisdictional disputes and closed it to state regulation except as concerns industries engaged in purely intrastate commerce. ${ }^{171}$ Seven states currently have statutory provisions regulating or prohibiting strikes in connection with jurisdictional disputes. ${ }^{172}$ All such laws were enacted in the forties, prior to the great pre-emption decisions of the Court in the O'Brien ${ }^{173}$ and Bus Employees ${ }^{174}$ cases.

\section{LicENSING, REgISTRATION AND REPORTING REQUIREMIENTS FOR UNIONS AND UNION REPRESENTATIVES}

The Wagner Act contained no provision concerning the licensing of union agents, the registration of unions, or the making of any financial reports. This

154 Kan. Stat. Ann. § 44-809a(1) (Supp., 1955).

${ }^{165}$ Id., at $\$ 41-809 \mathrm{a}$. Other attempts to protect agricultural operations from interferences by secondary boycotts have had rough sailing in the courts. AFL v. Langley, 66 Idaho 763, 168 P.2d 831 (1946); AFL v. Bain, 165 Ore. 183, 106 P.2d 544 (1940).

${ }^{166}$ During 1956 such disputes resulted in 212,000 man-days of idleness in the United States, which though not insignificant in the absolute, constitute only slightly over one-half of one percent of the total man-days lost due to strikes in that year. Herlihy and Moede, Analysis of Work Stoppages During 1956, 80 Monthly Lab. Rev. 565, 568 (1957).

${ }^{167}$ Labor Management Relations Act, 1947, at $\S 8(b), 61$ Stat. 142 (1947), 29 U.S.C.A. $\S 158(\mathrm{~b})(4)(\mathrm{D})(1956)$.

${ }^{168}$ Labor Management Relations Act, 1947, at $\$ 10\left(e^{*}, 61\right.$ Stat. 147 (1947), 29 U.S.C.A. $\S 160(\mathrm{e})(1956)$.

${ }^{162}$ Labor Management Relations Act, 1947, at $\S 10(\mathrm{k}), 61$ Stat. 149 (1947), 29 U.S.C.A. $\S 160(\mathrm{k})(1956)$.

${ }^{170}$ Labor Management Relations Act, 1947, at $\$ 303(b), 61$ Stat. 154 (1947), 29 U.S.C.A. $\S 187(\mathrm{~b})(1956)$.

${ }^{171}$ In Weber v. Anheuser-Busch, Inc., 348 U.S. 468 (1955), the court refused to permit a state court to enjoin as an illegal restraint of trade under its common law and conspiracy statutes conduct which the Board had found did not violate $\$ 8(\mathrm{~b})(4)(\mathrm{D})$. "Controlling and therefore superseding federal power cannot be curtailed by the State even though the ground of intervention be different than that on which federal supremacy has been exercised." Id., at 480 .

${ }^{172}$ California, Florida, Iowa, Kansas, Mrinnesota, Pennsylvania, and Wisconsin.

173.339 U.S. 454 (1950). $\quad 174340$ U.S. 383 (1951). 
omission notwithstanding, the Supreme Court held invalid, as applied to an employer engaged in interstate commerce, a Florida statute requiring the licensing of union business agents and the filing of annual reports by labor organizations. ${ }^{175}$ The Court reasoned that since the Florida statute prevented the union and its selected representatives from functioning as collective bargaining agents except upon conditions fixed by Florida, the state law interfered with the full freedom of employees under the Wagner Act to select bargaining representatives of their own choosing. ${ }^{176}$ Where failure to file the required report does not prevent a union from continuing to function as a bargaining agent but only imposes a reasonable fine, the constitutional vulnerability under the Supremacy Clause seems much more doubtful. ${ }^{177}$

The Taft-Hartley Act continued the right of employees to bargain collectively through representatives of their own choosing. ${ }^{173}$ In addition, Section 9(f) and $(\mathrm{g})$ of the amended Act requires a labor organization, in order to be "in compliance," to file certain reports annually with the Secretary of Labor relating to its constitution and its finances. ${ }^{179}$ Thus, quite apart from the direct conflict between federal and state provisions which the Court found in the Hill case, an additional argument of pre-emption is to be anticipated as regards state registration and reporting laws in view of the filing and reporting provision of the Taft-Hartley Act. ${ }^{180}$ An employer cannot justify his refusal to bargain with a duly selected representative of the workers on the ground that the union representative failed to comply with a state licensing law. ${ }^{181}$

Another limitation on the power of a state to license union representatives lies in the Fourteenth Amendment. In Thomas $\%$. Collins ${ }^{182}$ a divided Court held that a state could not constitutionally prohibit a labor official, who had not secured a state license, from delivering a prosunion speech to potential members. The Court, however, indicated that a different result might follow when the speaker engages in conduct which goes beyond the right of free discussion, "as when he undertakes the collection of funds or securing subscriptions, he

376 Hill v. Florida, 325 U.S. 538 (1945).

${ }^{176}$ Another author has cited a conflict between the right "to form, join, or assist labor organizations" in this section and Iocal licensing. Note, Validity of Statutes and Ordinances Requiring the Licensing of Union Organizers, 70 Harv. L. Rev. 1271, 1281 (1957).

177 Alabama State Federation of Labor v. Mc. Idory, 325 L.S. 450 (1943). Failure to file has been held not to make recognition picketing unlawful. Shiland v. Retail Clerks, $259 \mathrm{Ala}$. 27i, 66 So.2d 146 (1953).

${ }^{178}$ Labor Management Relations Act, 1947, at $\S 101(1), 61$ Stat. 137 (1947), 29 U.S.C.A. $\S 151$ (1956).

${ }^{179}$ Labor Management Relations Act, 1947, at $\$ 9(f)$ and (g), 61 Stat. 145 (1947), 29 U.S.C.A. §159(f) (1956).

${ }^{180}$ Dissenting in Hill v. Florida, Mr. Justice Frankfurter noted that the Wagner Act contained no restrictions as to unions. 325 U.S. 538, 558-59 (1945).

181 Eppinger \& Russell Co., 56 N.L.R.B. 1259 (1941).

182323 U.S. 516 (1945). 
enters a realm where a reasonable registration or identification requirements may be imposed."183

A number of states have passed licensing, reporting and registration statutes covering unions and union officials. Five jurisdictions require unions to file detailed annual financial statements with the state. ${ }^{184}$ Two jurisdictions make the state's copy available to any member, ${ }^{185}$ one jurisdiction makes it available to selected public officers, ${ }^{186}$ one specifically makes it public, ${ }^{187}$ while the other is silent on the point. ${ }^{188}$ Wisconsin provides a procedure where a member can petition the labor relations board for an order directing the union to furnish such a report. ${ }^{189}$ Florida $^{190}$ and Massachusetts ${ }^{191}$ impose simple registration procedures, failure to comply being punishable by fine in Massachusetts and by fine or imprisonment in Florida. Similarly, Florida requires the registration and licensing of business agents as a condition of serving as a union representative, and provides that no license shall issue to any convicted felon or person not of good moral character or person who has not been a citizen for ten years. ${ }^{192}$ Texas requires an applicant to be of good moral character and disqualifies aliens as well as felons whose rights of citizenship have not been restored, ${ }^{193}$ while Kansas merely requires that an applicant be a citizen. ${ }^{194}$

The greatest activity in the licensing field is now found not at the state but at the county and municipal level and almost all in the South. In 1956 Barnwell County, South Carolina, adopted an ordinance requiring that a permit be obtained from the County Board of Managers to solicit members for any union. It permits the Board "to refuse to issue a permit for any just reason and for the peace and good order of the citizens of Barnwell County." "195 Similar ordinances were enacted in 1957 covering eight other counties in South Carolina. ${ }^{196}$

${ }^{183} \mathrm{Id}$., at 540.

18 Ala. Code (1940) Title 26, $\$ 382$ (Supp., 1955); Conn. Pub. Acts (1915) No. 628; Kan. Gen. Stat. (1949) \$41806; S.D. Code (1939) \$17.1105 (Supp., 1943); Tex. L. Ann. (Vernon, 1957) Title 83, Art. 5154a, $\$ 3$. Similar provisions in two other states have been held invalid due to other defects in the statutes. AFL v. Langley, 66 Idaho 763, 168 P.2d 831 (1946); AFL v. Reilly, 113 Colo. 90, 155 P.2d 145 (1945).

${ }^{185}$ Ala. Code (1940) Title 26, § 382 (Supp., 1955); Conn. Pub. Acts (1945) No. 628.

${ }^{1 \times 5}$ Puerto Rico L. Ann. (1955) Title 29, c. 3, $\$ \$ 61$ et seq.

${ }^{1 \times} \mathrm{Ibid}$. Such information can be important to an employer engaged in a strike. On August 23,1957 , the United States Senate passed and sent to the House Senate Joint Resolution 94, which requires the Secretary of Labor to make public financial and other information unions are required to file with the Department of Labor under the Taft-Hartley Act.

${ }^{1 \times 8}$ Hawaii L. (1945) c. $72 \mathrm{~A}, \S 4150.10 . \quad{ }^{190}$ Fla. Stat. Ann. (1952) $\$ 447.06$.

${ }^{180}$ Wis. Stat. Ann. (West, 1957) $\$ 111.08$. $\quad{ }^{191}$ Mass. Ann. L. (1946) c. 618, $\$ 1$.

${ }^{192}$ Fla. Stat. Ann. (1952) $\$ 447.04$.

${ }^{193}$ Tex L. Ann. (Vernon, 1947) Art. 5154a, $\$ 4 a$.

134 Kan. Stat. Ann. (1949) § 44-804.

${ }^{195}$ S.C. Acts (1956) Act $948, \$ 5$. Each act of solicitation without a permit can be punished by a fine of not more than $\$ 500$ or imprisonment for not more than 90 days or both.

${ }^{108}$ S.C. Acts (1957) Acts 248, 340, 477, 478, 484, 537, 605, 689. 
The United States Supreme Court has noted probable jurisdiction over a case involving a Georgia ordinance that authorizes the licensing authorities to "consider the character of the applicant, the nature of the business of the organization for which members are desired to be solicited, and its effects upon the general welfare of citizens of the City," and imposes an annual license fee of $\$ 2000$, plus $\$ 500$ for each member obtained. ${ }^{197}$ A Carroliton, Georgia ordinance sets an initial license tax of $\$ 1000$, plus $\$ 100$ "at the beginning of each twenty-four hour period of each day."198

\section{SUABILITY}

The modern problem relative to the enforcement of collective bargaining agreements arose because unions as unincorporated associations were not legal entities at common law and could not sue or be sued in their own name. While an association might be sued at common law by joining all of its members as defendants, the procedure was often so cumbersome and the outcome so doubtful that a Senate committee classified it as "an almost impossible process."199 While the Wagner Act required employers to incorporate agreements reached with unions into signed collective bargaining contracts, ${ }^{200}$ it contained no provision relative to the enforcement of such contracts.

Section 301(a) of the Taft-Hartley Act was designed by the sponsors of the bill to do away with the common law disabilities in the way of unions suing or being sued for breach of contract. ${ }^{201}$ While the section has done much to facilitate suits against unions for breach of contract, the Westinghouse decision ${ }^{202}$ has clouded the picture; at least as far as concerns the right of unions to sue. Although many of the ramifications of this case are largely beyond the scope of this article, ${ }^{203}$ it seems clear that a state forum will have to be found in many situations where diversity of citizenship and the federal jurisdictional amount are lacking. ${ }^{204}$ Still unresolved at an authoritative level is the question of

${ }^{197}$ Staub v. Baxley, 94 Ga.App. 18, 93 S.E.2d 375 (1956), probable jurisdiction noted, 352 U.S. 962 (1957). The state court held that the failure of the defendant, who was convicted of soliciting members without a license, to attempt to secure a license precluded her from having the standing to attack the validity of the ordinance.

198 Denton v. City of Carrollton, Georgia, 235 F.2d 481 (C.A. 5th, 1956).

${ }^{199}$ Senate Committee Report on S.1126, Report No. 105, April 17 (legislative day;, March $24), 1947$. For a general discussion of the law relating to the enforceability of collective bargaining agreements, see Gregory and Katz, Labor Law Cases: Materials and Comments 11521163 (1948).

${ }^{200}$ H. J. Heinz Co. v. NLRB, 311 U.S. 514 (1941).

201 Senate Report No. 105 on S. 1126 at 15 (1947).

${ }^{202}$ Association of Westinghouse Salaried Employees v. Westinghouse Corp., 348 U.S. 437 (1955).

${ }^{203}$ The case is discussed in 1 A.L.R.2d Supp. Serv. 1070 (1957), and 50 Vw. U. L. Rev. 289 (1955).

${ }^{204}$ Section 301(a) has provided parties to collective bargaining agreements with a convenient forum for the enforcement of arbitration awards and agreements to arbitrate. Textile 
whether Section 301(a) has pre-empted the field of contract enforcement or whether it permits concurrent jurisdiction by state courts. The language of Section 301(a) that suits for violation of contract "may" be brought in any federal district court has been interpreted as evidencing a desire by Congress not to create exclusive jurisdiction in the federal judiciary. ${ }^{205}$ But the weight of authority up to this time seems to attach such pre-emption to actions for damages for breach of contract, ${ }^{206}$ but not to actions for injunctive relief. ${ }^{207}$ The recent decision of the Supreme Court holding that Section 301(a) creates a new federal substantive law "which the courts must fashion from the policy of our national labor laws," 208 offers a considerable obstacle to those who argue for concurrent jurisdiction in the face of the great pre-emption decisions of recent years.

At the state level twenty-three jurisdictions now explicitly permit unions to sue and be sued. ${ }^{209}$ In addition, unions sometimes sue or are sued by the use of class actions. ${ }^{210}$ Six states make breach of contract by a union an unfair labor practice, and all of this group but Kansas make an employer breach of contract a corresponding violation of law. ${ }^{211} \mathrm{~A}$ labor organization is not a legal entity in

Workers v. Lincoln Mills, 353 U.S. 448 (1957). For a study of state laws, see Note, State Arbitration Statutes Applicable to Labor Disputes, 19 Mo. L. Rev. 280 (1954). On the question of arbitration of new contract terms, see Note, Federal Enforcement of Agreements to Arbitrate New Contract Terms, 52 Nw. U. L. Rev. 284 (1957). See also Wyle, Unions in Search of a Forum to Enforce Contracts, 7 Lab. L. J. 425 (1956).

${ }^{206}$ Castle \& Cooke Terminals v. Local 137, 110 F. Supp. 247 (Hawaii, 1953).

${ }^{206}$ Fay v. American Cystoscope Makers, 98 F. Supp. 278 (S.D. N.Y., 1951); McCarroll v. Los Angeles County District Council of Carpenters, 39 L.R.R.M. 2285 (Cal. Dist. Ct. of App., 2d Dist., 1956); Colgate Co. v. Warehouse Union, 36 L.R.R.M. 2334 (Cal. Dist. Ct. of App., 1st Dist., 1955).

${ }^{207}$ General Bldg. Contractors Ass'n v. Local Union No. 542, 370 Pa. 73, 87 A.2d 250, 32 A.L.R. 2d 829 (1952); General Electric Co. v. International Union, 93 Ohio App. 139, 108 N.E.2d 211 (1952), appeal dismissed 158 Ohio St. 555, 110 N.E.2d 424 (1953); Sheet Metal Wkrs. Int. Ass'n. v. E. W. Daniels P. \& H. Co., 223 Ark. 48, 264 S.W.2d 597 (1954). See in this connection the excellent opinion of Judge Rifkind in Alcoa S.S. Co. v. McMahon, 81 F. Supp. 541 (S.D. N.Y., 1948), holding that the federal district courts are without jurisdiction to grant an injunction under Section 301(a). But it has been held that they do have jurisdiction to grant specific performance of a no-strike clause in a collective bargaining agreement. A. H. Bull Steamship Co. v. Seafarers' International, 33 CCH Lab. Cas. T 71,019 (S.D. N.X., 1957).

208 Textile Workers v. Lincoln Mills, 353 U.S. 448 (1957).

${ }^{203}$ Alabama, Arkansas, Colorado, Connecticut, Florida, Hawaii, Kansas, Louisiana, Maine, Maryland, Minnesota, Montana, Nebraska, New Jersey, New York, Oklahoma, Rhode Island, South Carolina, South Dakota, Utah, Vermont, Virginia, Wyoming. The provisions of the Taft-Hartley Aci. apply to all industries within Alaska, District of Columbia, Hawaii and Puerto Rico.

${ }^{210}$ Donovan v. Danielson, 244 Mass. 432,138 N.E. 811 (1923).

${ }^{211}$ It is an unfair labor practice for employers and employees to breach their collective bargaining agreements in the following jurisdictions: Colo. Rev. Stat. (1953) c. 80-5-6(1)(f); Minn. Stat. Ann. (1947) \$179.12(1); Wis. Stat. Ann. (West, 1957) § 111.06(1)(f); Hawaii L. (1945) c. $72 \mathrm{~A}, \S 4150.08(\mathrm{f})$; Puerto Rico L. Ann. (1955) Title $29, \S 69(\mathrm{f})$. 
Nevada but by statute an employee may sue a union for damages due to an illegal union-security provision. ${ }^{212}$ In Massachusetts a union corporation may be formed which can sue and be sued in its own name, but since unions have rarely been known voluntarily to incorporate, and since compulsory incorporation has been held unconstitutional, ${ }^{213}$ the entire subject of incorporation is of little present significance.

While there has unquestionably been comparatively little common law litigation arising between parties to collective bargaining agreements, this author does not believe that it results principally from procedural difficulties but rather from the general acceptance of the principle of voluntary arbitration and the obviously disruptive influence of law suits in situations where the parties must continue to live and work together.

\section{Political Contributions}

Prior to the 80th Congress, which passed the Taft-Hartley Act prohibiting any "contribution or expenditure" in connection with any federal election, six states had prohibited such activity (two of these statutes were held invalid and a third repealed). ${ }^{215}$ The Supreme Judicial Court of Massachusetts had held that an initiative measure prohibiting political activity by labor unions would be unconstitutional if enacted because "the result would be to abridge even to the vanishing point any effective freedom of speech, liberty of the press, and right of peaceable assembly." 116 In $1955 \mathrm{New}$ Hampshire and Wisconsin banned political contributions by unions as well as by employers. ${ }^{217}$ Only Texas prohibits solely union contributions. ${ }^{218} \mathrm{New}$ York and Wisconsin make illegal a political contribution from any employee welfare fund. ${ }^{219}$

The Wisconsin law makes clear the right of any individual "to form, join, contribute to or participate in voluntary political organizations . . other than labor organizations or labor unions. . . "

${ }^{212}$ Nev. Rev. Stat. (1957) Title 53, § 613.290.

${ }^{213}$ AFL v. Reilly, 113 Colo. 90, 155 P.2d 145 (1945).

${ }^{214}$ The Wagner Act did not attempt to regulate the political activities of labor unions.

${ }^{215}$ Ala. Gen. Acts (1943) No. 298, $\$ 17$ (invalidated on procedural grounds); Colo. Stat. Ann. (Michie, Supp., 1946) c. 97, $\$ 94(20)(4)$ (c) (invalidated because an earlier provision in the section was held to be unconstitutional); Del. L. (1947) c. 196, $\$ 23$ (repealed in 1949); Ind. Stat. Ann. (1949) $\$ \$ 29-5712$, 29-5965; Pa. L. (1943) No. 358, $\$ 1605$ (b); Tex. L. (194j) c. 104, $\S 4$ (b).

${ }^{216}$ Bowe v. Secretary of the Commonwealth, 320 Mass. $230,252,69$ N.E.2d 115, 130 (1946). But cf. American Federation of Labor v. Mann, 188 S.W.2d 576 (Tex. Civ. App., 1955), where the Texas Court of Civil Appeals upheld a Texas statute prohibiting political contributions by unions.

${ }^{217}$ See note 214 supra.

${ }^{218}$ See note 215 supra.

${ }^{219}$ N.Y. Ins. Law (1949) § 37-a (Supp., 1957); Wis. Stat. Ann. (West, 1957) § 211.14(3).

${ }^{220}$ Wis. Stat. Ann. (West, 1957) $\$ 12.56(1)(b)$. 
United States Supreme Court decision construing Section 304 of the Taft-Hartley Act, 221 that nothing "shall prohibit the publication by labor unions . . . in the regular course of conducting their affairs, of periodicals advising their members of dangers or advantages to their interests of election to office of men espousing certain measures." 2222

Twenty-seven states and two territories have enacted laws permitting employees to take time off from work to vote. ${ }^{223}$ Fifteen states, Alaska and Hawaii require payment for such time lost up to varying maximums of from one to four hours. ${ }^{224}$ There has been a marked trend in recent years to allow time off only if there is not sufficient time to vote outside working hours, nine jurisdictions so providing by legislative action and Texas by an opinion of the Attorney General. ${ }^{225}$ The highest courts in Kentucky and Illinois have held provisions requiring payment for time off to be unconstitutional, ${ }^{226}$ but the United States Supreme Court has sustained the constitutionality of a similar Missouri statute. ${ }^{227}$

\section{Regulation OF Welfare FundS}

During the forties many factors combined to set the stage for the recent development of state legislation regulating welfare and pension plans. The financial incentive to the growth of these plans was a provision in the Revenue Act of 1942 which made it easier for employers to set up qualified plans, contributions to which became deductible from gross income. ${ }^{228}$ The wartime program of high excess profits taxes with a wage stabilization program, the Krug-Lewis agreement in 1946 establishing a pension and welfare plan in the bituminous coal industry, and the successful 1949 steel strike were important to the growth of benefit plans. In 1949 also the courts enforced NLRB decisions requiring employers to bargain on the subjects of welfare ${ }^{229}$ and pension plans. ${ }^{230}$ The result of all this was that $11,290,000$ workers in the United States were, by 1955 , covered by some type of health and insurance or pension plan under collective bargaining agreements. ${ }^{231}$

221 United States v. CIO, 335 U.S. 106 (1948). See also United States v. Painters Union Lacal No. 481, 172 F.2d 854 (C.A. 2d, 1949).

222 See note 220 supra.

${ }^{223}$ State Legislation on Time Off From Work for Voting, 79 Monthly Lab. Rev. 1166 (1956).

224 Ibid. 225 Ibid.

221 Illinois Central Railroad Co. v. Kentucky, 305 Ky. 632, 204 S.W.2d 973 (1947); Heimgaertner v. Benjamin Electric MIanufacturing Co., 6 III.2d 152, 128 N.E.2d 691 (1955). The Illinois legislature in 1957 extended the closing time of polls one hour, which is another means of accomplishing the same objective.

227 Day-Brite Lighting, Inc. v. Missouri, 342 U.S. 421 (1952).

22: 56 Stat. 798 (1942).

${ }^{229}$ W. W. Cross \& Co. v. NLRB, 174 F.2d 875 (C.A. 1st, 1949).

${ }^{230}$ Inland Steel v. NLRB, 170 F.2d 247 (C.A. 7th, 1948), cert. denied 336 U.S. 960 (1949).

231 Rowe, Health, Insurance, and Pension Plans in Union Contracts, 78 Monthly Lab. Rev. 993 (1955). 
While the Labor Management Relations Act of 1947 promoted the widespread growth of these plans by requiring bargaining on them, Section 302 of that Act set forth certain controls "on the theory that union leaders should not be permitted ... to divert funds paid by the company ... to the union treasury or the union officers, except under the process of strict accountability.' "232

Section 302 permits employer payments to a trust fund established by the representative of the employees only if these conditions are met: the payments from the trust fund must be for the health or benefit of the employees, their families and dependents; the trust must be based on a written agreement between the employer and the union providing the detailed basis on which such payments are to be made; joint administration of the fund with provisions for the selection of an impartial trustee to act in the event of a deadlock; annual audit and a separate trust fund for pensions or annuities. A violator is subject to a $\$ 10,000$ fine, or imprisonment for one year, or both..$^{233}$

In January of 1954 a Senate subcommittee was to conclude after an extensive investigation, "Experience has shown that the statute is an ineffective instrument for the regulation and control of welfare and pension trusts arising out of collective bargaining contracts." consensus of the subcommittee that current State insurance, investment, and trust laws, in their general application, do not afford the means for effective regulation of private employee welfare and pension funds as separate and distinct legal entities." ${ }_{235}$ The states were quick to take the cue. That same year New York passed a law, stating that "the superintendent of Insurance in order to protect the interests of the people of this state, may examine into the affairs of any employee welfare trust fund as often as he deems it expedient, but at least once in every five years. . ."236 A more extensive law requiring reporting and

232 See note 234 infra.

${ }^{233}$ Id., at $\$ 302$ (d). One interesting question never passed upon by the Supreme Court is whether the pre-emption doctrine would apply with equal force where the federal legislation in question is criminal rather than part of the National Labor Relations Act administered by the NLRB. One state supreme court has squarely held that the present criminal provisions in Section 302(c) (4) pre-empt the area of check-off legislation. Utah v. Montgomery Ward \& Co., 120 Utah 294, 233 P.2d 685 (1951).

234 Interim Report submitted to the Committee on Labor and Public Welfare by its Subcommittee on Welfare and Pension Funds, p. 31, pursuant to Sen. Res. 225, 100 Cong. Rec. 5622, as amended by Sen. Res. 270, 100 Cong. Rec. 10759, and Sen. Res. 235, 102 Cong. Rec. 5901 (1955).

${ }^{235}$ Id., at p. 39. For the extent to which unions are themselves seeking to eliminate objectionable practices in connection with health and welfare funds, consult Codes of Ethical Practices of the Labor Movement, 80 Monthly Lab. Rev. 350-51 (195i). These codes, which set forth strict ethical standards of conduct for union officials, were formally adopled by the American Federation of Labor and Congress of Industrial Organizations in January, 1957.

${ }^{236}$ N.Y.L. (1954) c. 278 , effective until Sept. 1, 1956.

The new law reads: " 1 . The superintendent may examine into the affairs of any employee welfare fund as often as he deems it necessary, and he shall do so at least once in every five years. 2. The trustees of every employee welfare fund shall be responsible for the maintenance 
inspection of the funds was adopted in Washington in $1955,{ }^{237}$ while a similar law was passed in New York but vetoed. A California statute in 1955 made it a misdemeanor for an employer wilfully or with intent to defraud to fail to make payments required under an agreement calling for employer contributions to a welfare fund, ${ }^{238}$ while a similar law was adopted in 1957 in Nevada, ${ }^{239}$ Alaska $^{240}$ and Oregon. ${ }^{241}$ In 1957 California, ${ }^{242}$ Connecticut ${ }^{243}$ and Wisconsin ${ }^{244}$ passed comprehensive statutes regulating welfare funds, while New York further strengthened its $1956 \mathrm{law}^{245}$ All of these statutes establish supervision over the covered plans, require periodic reporting, and prohibit payments to any trustee, employer or labor organization, or their agents, from any insurance company, insurance broker, or hospital, surgical or medical service plan. New York $^{246}$ and Wisconsin ${ }^{247}$ provide specific criminal penalties as well as injunctive relief while Connecticut ${ }^{243}$ and California ${ }^{249}$ permit the Commissioner to bring a civil suit. New York also followed the lead of a 1955 Florida statute which had required that any dividend or refund under a group insurance policy be applied for the sole benefit of the insured employees. ${ }^{250}$

The New York law is applicable only to jointly administered plans, which limitation drew the criticism but not the veto of Governor Harriman. ${ }^{251}$ The Connecticut law covers all jointly established funds, however administered, ${ }^{252}$ while the California law covers all negotiated plans. ${ }^{253}$ The Wisconsin statute

of accurate records of its books and accounts in conformance with generally accepted accounting principles and with any regulations prescribed with regard thereto." N.Y. Ins. Law (McKinney, 1949) §37-c (Supp., 1957).

237 Wash. Rev. Code (1955) $\$ \$ 48.52 .010-48.52 .080$.

${ }^{23 y}$ California v. Alves, 13 W.H. 317 (Cal. Mun. Ct., 1957), holding this statute invalid as an imprisonment for debt where the wilful failure to pay is caused by inability to pay, but valid where there is an intent to defraud. (1957).]

${ }^{233}$ Nev. Rev. Stat. (1957) c. 613, as amended by Assembly Bill No. 52. [See 38 S.L.L. 277

240 Alaska Comp. L. Ann. (1949) \$43-2-13.

241 Ore. L. (1957) c. 548, effective Aug. 19, 1957.

${ }^{242}$ Cal. L. (1957) c. 2167, effective Sept. 11, 1957.

${ }^{243}$ Conn. L. (1957) Pub. Act 594, effective Oct. 1, 1957.

244 Wis. L. (1957) c. 552, effective Aug. 22, 1957.

${ }^{245}$ N.Y. Ins. Law (McKinney, 1949) $\$ 37$ (Supp., 1957).

${ }^{245} \mathrm{Id}$., at $\$ 37-\mathrm{m}$. $\quad 247$ Wis. Stat. Ann. (West, 1957) \$211.14-15.

${ }^{248}$ Conn. L. (1957) Pub. Act. 594, \$11(b)(c).

${ }^{243}$ Cal. L. (1957) c. $2167, \S 10652$.

${ }^{250}$ Flarida statute, reported in 16 S.L.L. 279 (1956); N.Y. Ins. Law (McKinney, 1949) $§ 37$ (Supp., 1957).

25142 S.L.L. 298a (1957). $\quad{ }^{252}$ Conn. L. (1957), Pub. Act 594.

${ }_{253}$ See note 242 supra. In contrast, a Massachusetts law exempts all benefit plans resulting from labor-management agreements from state insurance regulations. Mass. Ann. L. c. 175, 
applies to all welfare funds solely or jointly established or administered. ${ }^{254}$ 'The Connecticut law permits either party, or "ten per cent of the employees or one hundred employees, whichever is less," to request an examination into any welfare fund by the commissioner of insurance. ${ }^{355}$

The regulation of welfare funds is still a new area of legislative activity for the states. It is, however, unquestionably an area in which much constructive thinking and legislating will be done in the near future.

\section{Fair Employment Practice Laws}

Strong opposition in the Congress, principally sectional in nature, has prevented the enactment of any federal legislation outlawing discriminatory employment practices. ${ }^{256}$ As a result, this vital area was left entirely open to the states. Many states have responded with constructive and effective legislation.

Sixteen jurisdictions-six in the east, four in the west, five in the midwest and one territory-have enacted fair employment practice legislation. ${ }^{257}$ They are of three basic types: those which rely solely on voluntary means, such as education, for implementation of the state policy against discrimination, ${ }^{258}$ one jurisdiction that provides only for statutory enforcement to implement the legislative policy, ${ }^{259}$ and the vast majority that seeks to effectuate the state's anti-discrimination policy both by education and by an enforcement procedure

$\$ 29$ (1955). However, Massachusetts recently enacted a new and comprehensive law, effective October 1, 1958, which establishes a Health, Welfare and Retirement Funds Board to which full and periodic reports must be given by all pension, retirement and insurance funds. Mass. L. (1957) c. 778.

254 See note 244 supra.

${ }^{255}$ Conn. L. (1957), Pub. Act 594.

${ }^{256}$ By Executive Order in May, 1943, President Roosevelt created the first federal Fair Employment Practices Commission in connection with the obtaining of full utilization of manpower in the war effort. The Commission was empowered to investigate complaints of racial discrimination in employment and to try to eradicate such practices. The first FEPC expired in June, 1946, but it was revived by President Truman in 1951. In 1953, President Eisenhower established a government contract committee to eliminate discriminatory practices by government contractors. Morgan, An Analysis of State FEPC Legislation, 8 Lab. L. J. 469 (1957).

${ }^{267}$ Alaska L. (1953) c. 18; Colo. Anti-discrimination Act of 1957, S.B. 126, L. 1957; Conn. Rev. Stat. (1949) c. 371, $\$ 7400$ et seq.; Ind. Stat. Ann. (Burns, 1952) $\$ \$ 40-2301$ et seq.; Kan. Gen. Stat. Ann. (Supp., 1953) c. 44, Art. 10; Mass. Ann. L. (Michie, 1955) c. 6, $\S 56 ;$ c. $151 \mathrm{~B}$; Mich. Stat. Ann. (Supp., 1955) Title $17, \$ \$ 17.458(1)$ et seq.; Minn. Stat. Ann. (1957) c. 363; N.J. Stat. Ann. (Supp., 1956) Title 18, c. 25; N.M. Stat. Ann. (1953) c. 59, Art. 4, $\$ \$ 59.4-1$ et seq.; N.Y. Bus. Corp. Law (AIcKinney, 1951) Art. 15; Ore. Rev. Stat. (1955) $\$ \$ 659.010$ et seq.; Pa. Stat. Ann. (Purdon, Supp., 1956) Title 43, c. 17, $\$ \$ 951$ et seq.; R.I.L. (1949) c. 2181 ; Wash. Rev. Code (1951) $\$ \$ 49.60 .010$ et seq.; Wis. Stat. Ann. (West, 1957) $\S \S 111.31$ et seq. The constitutionality of a state law prohibiting discrimination in employment was sustained in Railway Mail Assn. v. Corsi, 326 U.S. 88 (1945). The first enforcement proceeding under a state Fair Employment Practices Act is found in Holland v. Edwards, 122 N.Y.S.2d 721 (N.Y.S. Ct., 1st Dep't, 1953).

${ }^{258}$ Ind. Stat. Ann. (Burns, 1933) $\$ \S 40-2301$ et seq.; Kan. Gen. Stat. (Supp., 1953) c. 44, Art. 10.

${ }^{259}$ Alaska L. (1953) c. 18. 
backed up by judicial compulsion, where necessary. ${ }^{260}$ In addition to their direct enforcement program, these commissions generally are directed to study and report on discriminatory job practices, to conduct educational programs, to mediate and conciliate complaints of discrimination, and to make recommendations concerning the adjustment of such complaints ${ }^{261}$ and techniques and methods for implementing a fair practice program.

The heart of a typical fair employment practice statute is seen in the declaration of policy which in the Oregon law reads as follows:

(1) It is declared to be the public policy of Oregon that practices of discrimination against any of its inhabitants because of race, religion, color or national origin are a matter of state concern and that such discrimination threatens not only the rights and privileges of its inhabitants but menaces the institutions and foundation of a free democratic state.

(2) The opportunity to obtain employment without discrimination because of race, religion, color or national origin hereby is recognized as and declared to be a civil right. ${ }^{262}$

All of the fair employment laws, except Kansas and Wisconsin, establish unfair employment practices by employers, by unions and by employment agencies. Seven of the laws specifically define discrimination so as to cover "segregation or separation" as such. ${ }^{263}$ Not only do the state laws prohibit discrimination based on race, creed, color, national origin or ancestry, but the form of statutory language prohibits the printing or circulation of any statement, advertisement or publication, or the use of any application for employment or the questioning of prospective employees "which expresses, either directly or indirectly, any [such] limitation, specification or discrimination. ..."264 Employers can make religious or racial specifications only where

${ }^{250}$ Colo. L. (1957) S.B. 126; Conn. Rev. Stat. (1949) c. 371, $\$ \$ 7400$ et seq.; Mass. Ann. L. (Michie, 1955) c. $6, \$ 56$; c. 151B; Mich. Stat. Ann. (Supp., 1955) Title 17, $\$ 17.458(1)$ et seq.; Minn. Stat. Ann. (1957) c. 363; N.J. Stat. Ann. (Supp., 1956) Title 18, c. 25; N.M. Stat. Ann. (1953) c. 59, Art 4, $\$ \$ 59-4$-1 et seq.; N.Y. Labor Law (McKinney, 1948) \& 220-e (Supp., 1957); Ore. Rev. Stat. (1955) $\$ \$ 659.010$ et seq.; Pa. Stat. Ann. (Purdon, Supp., 1956) Title 43 , c. 17, $\$ \$ 951$ et seq.; R.I.L. (1949) c. 2181 ; Wash. Rev. Code (1951) $\$ \$ 49.60 .010$ et seq.; Wis. Stat. Ann. (West, 1957) $\$ \$ 111.31$ et seq.

201 The New York Commission Against Discrimination has noted that in every one of the seventy-five complaints which it found to be meritorious, the unlawful practices were investigated and eliminated by conference and conciliation. First Annual Report of the New York State Commission Against Discrimination, quoted in Gregory and Katz, Labor Law: Cases, Materials and Comments 1019, 1021 (1948).

262 Ore. Rev. Stat. (1953) \$ 659.020.

${ }^{263}$ Conn. Rev. Stat. (1949) c. 371, \$ 7401(i); Kan. Gen. Stat. Ann. (Supp., 1953) §441002(9); Mich. Stat. Ann. (Supp., 1955) Title 17, § 17.458(2)(g); Minn. Stat. Ann. (1957) c. 363, \$363.01(10); N.MI. Stat. Ann. (1953) c.59, Art. 4, \$59-4-3(h); Pa. Stat. Ann. (Purdon, Supp., 1956) Title 43 , c. $17, \$ 954(\mathrm{~g})$; R.I.L. (1944) c. $2181, \$ 3(\mathrm{G})$.

201 Colo. Anti-discrimination Act of 1957, S.B. 126, approved March 13, 1957, § $5(4)$. This language prohibits "the use of a form or the making of an inquiry without regard to intent." See Rulings on Pre-Employment Inquiries of the New York State Commission Against Dis- 
"based upon a bona fide occupational qualification," as in a job for a religious organization or, in some of the states, where it "is required by and given to an agency of government for security reasons." ${ }^{265}$

Eleven of the states place the administration of the statute in an administrative agency especially established for that purpose. ${ }^{266}$ Wisconsin vests the administration of its act in its Industrial Commission, Oregon in its Bureau of Labor, and Indiana in a Director of Fair Employment Practices appointed by the Director of Labor, and in all of these states a public advisory board is created. The principal function of all of the anti-discrimination agencies is to receive and investigate complaints, and all but Indiana's and Kansas's may issue cease and desist orders judicially enforceable against the offending party. An interesting and effective enforcement innovation is found in several of the states where, unlike under the typical state and federal labor relations statutes, the order of the agency becomes final unless a proceeding to obtain judicial review is filed by the respondent within a limited number of days, usually thirty. ${ }^{267}$ The burden of going ahead is thus shifted to the respondent. After this period has passed, the agency can obtain court enforcement simply upon a showing that the agency had jurisdiction over the respondent and that the action is being brought in the proper county. Mere inaction by the respondent for thirty days after an order of the state commission results in enforceability attaching to the order without contest on its merits. This is quite in contrast to labor board proceedings where the orders carry no sanction unless and until they have been judicially reviewed and enforced. A new trial in the enforcement proceedings-a trial de novo-may be had on a timely appeal in Alaska and New Mexico. ${ }^{268}$ New Mexico implements its law by requiring nondiscrimination clauses in every contract to which the state or any of its subdivisions is a party. Nine states make their laws applicable to state agencies. ${ }^{269}$

crimination, 4A CCH Lab. Law Rep. 45, 104 (1950). In this regard they go beyond the National Labor Relations Act, where interrogation as to union membership or sympathy per se is no longer considered unlawful but the legality is dependent on the circumstances surrounding the inquiry. Matter of Blue Flash Express, 109 N.L.R.B. 591 (1954).

${ }^{265}$ Colo. Anti-discrimination Act of 1957, S.B. 126, approved March 13, 1957, $\$ 5$ (4).

${ }^{266}$ Conn. Rev. Stat. (1949) c. $371, \S 7400$; Kan. Gen. Stat. Ann. (Supp., 1955) § 44-1003; Mass. Ann. L. (Michie, 1952) c. 6, §56; Mich. Stat. Ann. (Supp., 1955) § 17.458(5); Minn. Stat. Ann. (1957) § 363.04(1); N.J. Stat. Ann. (Supp., 1956) c. 25, § 18: 25-6; N.M. Stat. Ann. (1953) Art. 4, § 59-4-6; N.Y. Labor Law (McKinney, 1948) § 220-e (Supp., 1957); Pa. Stat. Ann. (Purdon, Supp., 1956) Title 43, c. 17, \$ 956; R.I.L. (1949) c. 2181, § 5; Wash. Rev. Code (1951) $\$ 49.60 .050$.

${ }^{267}$ Mich. L. (1955) Pub. Act 251, § 8(a)(5);N.M. Stat. (1953) §59-4-11(h); R.I. Acts (1949) c. $2181, \$ 9$; Alaska L. (1953) c. $18, \$ 8$. In Minnesota, only the Commission can commence proceedings after sixty days. Minn. Stat. Ann. (1957) $\$ 363.08(2)$. In Massachusetts, thirty days. Mass. Ann. L. (1949) c. 151B, §6.

${ }^{268}$ Alaska L. (1953) c. 18, § 9; N.M. Stat. (1953) § 59-4-11(a).

${ }^{269}$ Ind. Stat. Ann. (Burns, 1933) $\$ 40-2304$; Kan. Gen. Stat. Ann. (Supp., 1953) $\$ 44-1002$ (b); Mass. Ann. L. (Michie, 1955) c. 151B, §1(5); Mich. Stat. Ann. (Supp., 1955) \$17.458 
There has been a steady trend among the states toward the compuisory enforceable type of statute as against the voluntary type. There has also been a trend toward enlarging the scope of anti-discrimination laws. The New Jersey, Oregon and Washington Commissions administer laws which forbid discrimination in connection with public accommodations of all kinds. The Commissions in Oregon and Washington administer statutory provisions prohibiting discrimination in public housing. The Oregon agency is charged with administration of a law prohibiting discrimination in vocational, professional or trade schools. Massachusetts forbids any person in the insurance or bonding business to make any inquiry or record concerning race, color, creed or national origin of any person seeking a bond or surety bond conditioned upon the faithful performance of his duties.

An extremely interesting development is found in Massachusetts and Pennsylvania where the fair employment practice laws prohibit discrimination based on age. The protected age group in Massachusetts is between 45 and 65, and in Pennsylvania between ages 40 and 62 . Any business having 25 or more employees is prohibited in Louisiana from rejecting or discharging any employee "upon any age limit under 50 years. ..."270

The foregoing sets forth the chief legislative controls placed on labor relations and union organization and activities at the state level during the past two decades. The general trend away from the protective type of legislation and towards restrictive legislation has continued since 1939, but the fruition of the federal pre-emption doctrine has slowed the movement to a snail's pace. The relative shortness of the period studied and the general prosperity that has prevailed makes it still too early to assess the effect of restrictive legislation on union development and the collective bargaining process, but the prevalence of such regulatory laws in both the federal and state areas make it a vital subject for future study. In the meantime the states have been clearly circumscribed in the legislative field by the developing body of Supreme Court law giving broad application to the Supremacy Clause, but it is expected that increasing attention will be directed by the states in coming years to laws regulating welfare funds, internal union affairs and fair employment practices-all areas in which there exist little or no federal legislation. The primary conclusion that appears from a study of all of the state and federal legislation of the last two decades, and the court decisions rendered under them, is that for the first time there is gradually emerging a unified national labor policy in the United States.

(2)(b); Minn. Stat. Ann. (1957) $\$ 363.01$ (7); N.J. Stat. Ann. (Supp., 1956) Title 18, c. 25; N.גI. Stat. Ann. (1953) Art. 4, \$ 59-4-3(d); Pa. Stat. Ann. (Purdon, Supp., 1956) Title 43, c. $17, \$ 954$ (b); Wash. Rev. Code (1951) $\$ 44.60 .040$.

${ }^{270}$ La. Rev. Stat. (West, 1952) c. $23, \S 893$. 